Jones, G., Davies, S. M., Staff, R. A., Loader, N. J., Davies, S. J. and Walker, M. J. C. (2020) Traces of volcanic ash from the Mediterranean, Iceland and North America in a Holocene record from south Wales, UK. Journal of Quaternary Science, 35(1-2), pp. 163-174. (doi: 10.1002/jqs.3141).

There may be differences between this version and the published version. You are advised to consult the publisher's version if you wish to cite from it.

This is the peer reviewed version of the following article:

Jones, G., Davies, S. M., Staff, R. A., Loader, N. J., Davies, S. J. and Walker, M. J. C. (2020) Traces of volcanic ash from the Mediterranean, Iceland and North America in a Holocene record from south Wales, UK. Journal of Quaternary Science, 35(1-2), pp. 163-174, which has been published in final form at 10.1002/jqs.3141. This article may be used for non-commercial purposes in accordance with Wiley Terms and Conditions for Self-Archiving.

http://eprints.gla.ac.uk/197737/

Deposited on: 27 September 2019

Enlighten - Research publications by members of the University of Glasgow http://eprints.gla.ac.uk 


\title{
Traces of tephras from the Mediterranean, Iceland and North America in a Holocene record from South Wales, UK
}

Gwydion Jones, ${ }^{1}$ Siwan M. Davies, ${ }^{1}$ Richard A. Staff, 2,3 Neil J. Loader, ${ }^{1}$ Sarah J. Davies, ${ }^{4}$ and Michael J.C. Walker ${ }^{4,5}$

1. Department of Geography, Swansea University, Singleton Park, Abertawe, Cymru, SA2 8PP, UK

2. Scottish Universities Environmental Research Centre (SUERC), University of Glasgow, Scottish Enterprise Technology Park, Rankine Avenue, East Kilbride, Scotland, G75 0QF, UK

3. Research Laboratory for Archaeology and the History of Art (RLAHA), University of Oxford, Oxford, England, OX1 3QY, UK

4. Department of Geography \& Earth Sciences, Aberystwyth University, Penglais, Aberystwyth, Cymru, SY23 3DB, UK

5. School of Archaeology, History and Anthropology, Trinity Saint David, University of Wales, Lampeter, Cymru SA48 7ED, UK

Correspondance: G.Jones, as above.

Email: G.Jones@swansea.ac.uk

Key words: cryptotephra, Holocene, south Wales, far-travelled, Llyn Llech Owain.

\begin{abstract}
A tephra record is presented for a sediment core from Llyn Llech Owain, south Wales, spanning the early- to mid-Holocene. Seven cryptotephra deposits are discovered with three thought to correlate with known eruptions and the remaining four considered to represent previously undocumented events. One deposit is suggested to correlate with the $\sim 6.9$ cal ka BP Lairg A Tephra from Iceland, whereas more distant sources are proposed as the origin for two of the tephra deposits. A peak of colourless shards in early-Holocene sediments is thought to tentatively correlate with the $\sim 9.6$ cal ka BP Fondi di Baia Tephra (Campi Flegrei) and a second cryptotephra is tentatively correlated with the $\sim 3.6$ cal ka BP Aniakchak (CFE) II Tephra (Alaska). The Fondi di Baia tephra has never been recorded beyond proximal sites and its discovery in south Wales significantly extends the geographical distribution of ash from this eruption. The remaining four cryptotephra deposits are yet to be correlated with known eruptions, demonstrating that our current
\end{abstract}


understanding of widespread tephra deposits is incomplete. This new tephra record highlights the potential for sites at more southerly and westerly locations in NW Europe to act as repositories for ash from several volcanic regions.

\section{Introduction}

Tephra and cryptotephra deposits have long been recognised for their value in providing time-parallel markers and chronological tie-points for a range of proxy records (e.g., Pilcher et al., 1996; Davies et al., 2002; Turney et al., 2006; Griggs et al., 2014; Bourne et al., 2015; Timms et al., 2016; Abbott et al., 2018; Jones et al., 2018; Larsson and Wastegård, 2018). In NW Europe, the early origins of cryptotephra studies can be traced back to the 1960s with Persson's work in Scandinavian peatlands (Persson, 1966). However, it was the discovery of the Hekla 4 Tephra in a Scottish peatbog (Dugmore, 1989) that marked the start of systematic cryptotephra work within Holocene palaeoenvironmental studies. Tephra deposits have since become important chronological constraints within many Holocene records in NW Europe (e.g., Pilcher and Hall, 1992; Dugmore et al., 1995; Hall and Pilcher, 2002; Lawson et al., 2012; Wulf et al., 2016).

The majority of Holocene tephra deposits found in NW Europe are of Icelandic origin; however, a number of recent studies have revealed the presence of glass shards that originate from 'ultra-distal' sources from across the Northern Hemisphere (e.g., Jensen et al., 2014; van der Bilt et al., 2017; Watson et al., 2017a; Cook et al., 2018). The first 'ultra-distal' discovery was the White River Ash, sourced from Mount Churchill, Alaska and found preserved in peatlands in Ireland and Germany (Jensen et al., 2014). This discovery initiated new lines of investigation that extend far beyond Iceland, when searching for the volcanic source of unknown cryptotephra deposits. Plunkett and Pilcher (2018) have reviewed the published and un-published tephra datasets from sites in northwest Europe during the mid- to late-Holocene and, of the 90 unique tephra deposits identified, $24 \%$ originate from volcanic regions outside of Iceland, including Alaska, the Cascades, Kamchatka, Mexico, the Azores and the Mediterranean. These findings include shards similar to the Lipari Monte Pilato tephra and the Aniakchak Caldera Forming Eruption (CFE II) in Garry Bog, Ireland (GB4-45a and GB4-182b respectively) (Plunkett and Pilcher, 2018). 
In NW Europe the geographical distribution of reported ash finds is typically dominated by sites in northerly latitudes, with noticeable absences in France, southern England and Wales (e.g., Lawson et al., 2012; Wulf et al., 2016; Jones et al., 2017). For instance, in the British Isles, cryptotephra records are predominantly from localities in Scotland, northern England and Ireland (e.g., Pilcher and Hall, 1992; Turney et al., 2006; Matthews et al., 2011; Kelly et al., 2017; Timms et al., 2018). Questions have often been raised about whether sites in Wales and southern England are beyond the limits of the dominant ash plumes from Iceland, or whether this pattern is a reflection of the intensity of tephra searches in other regions. The need to adopt different methodologies that would facilitate the detection of considerably smaller ash particles in more distal areas has also been suggested (e.g., Kearney et al., 2018). Although traces of tephra were reported by Buckley and Walker (2002) in peat deposits in the Cambrian Mountains of central Wales, it was not until very recently that the potential of sequences, from Wales and southern England, as tephra repositories was confirmed (Jones et al., 2017; Watson et al.,2017b). The Askja-S Tephra was identified at Pant-y-Llyn, south Wales (Jones et al., 2017), volcanic glass shards from Hekla 1947, Hekla 1845 and MOR-T4 have been found at Cors Fochno in mid Wales (Watson et al., 2017b) and tentative correlations have been made with the White River Ash Eastern Lobe of Alaskan origin and AD 860 A tephras at Rough Tor in southern England (Watson et al., 2017b). Here we present a Holocene cryptotephra record for a new sequence in Wales, Llyn Llech Owain in Carmarthenshire, south Wales. We suggest that two of the tephras indeed originate from distant sources, one of which is more than 8000 km away.

\section{Study site and methods}

\subsection{Study Site}

Llyn Llech Owain (510 48' 55”N, 40 4' 44"W) is a small lake, approximately $250 \mathrm{~m}$ long and $200 \mathrm{~m}$ wide, located $4 \mathrm{~km}$ north of Cross Hands, south Wales (Fig. 1). The lake is approximately $260 \mathrm{~m}$ above sea level and lies within the Twrch Sandstone Formation (Upper Carboniferous: Waters et al., 2009). In 2005, a series of overlapping cores (LLO05) was taken from an infilled area at the western margin of the lake using a Russian-type peat sampler with a $5 \mathrm{~cm}$ by $1 \mathrm{~m}$ sampling 
chamber. At the coring site, over $8 \mathrm{~m}$ of sediment had accumulated, the lowermost 2-3 m comprising limnic deposits while the middle and upper parts of the sequence consist of organic muds and peats. Pollen analysis shows that the lower part of the profile contains a Lateglacial and early Holocene record (Walker and Jones, 2006; Walker et al., 2009a). A second core (LLO09) was taken in 2009 from close to the original sampling site for tephra analysis and, in 2013, a further series of Russian cores (LLO13) was recovered. The early Holocene tephra record from LLO09 and LLO13 is described here; results from the Lateglacial section of the sequence will be presented in a later paper.

The LLO13 and LLO09 cores are correlated on the basis of carbon content and LOI data for each respective record (see dashed lines in Fig. 2), and a proposed tephra correlation between LLO09_505 cm and LLO13_483 cm. The LLO05 core is correlated based on two lithostratigraphic tie-points which is presented in Walker and Jones (2006).

\subsection{Sediment chemistry}

Core LLO13 was scanned using the ITRAX core scanning facility at Aberystwyth University and was operated following the standard methodology outlined in Croudace et al. (2006). Carbon content was measured at $1 \mathrm{~cm}$ resolution from core LLO13 using a PDZ-Europa ANCA GSL Elemental Analyser. Loss on Ignition (LOI) was determined for LLO09 at $5 \mathrm{~cm}$ contiguous resolution, following the standard protocol of Heiri et al. (2001).

\subsection{Tephra sampling and analysis}

Tephra searches were conducted on $5 \mathrm{~cm}$ resolution contiguous samples from 520 $270 \mathrm{~cm}$ (early-mid Holocene) in core LLO09 and from 700-450 cm (early Holocene) in core LLO13, following the methodology developed by Turney (1998) and outlined in Davies et al. (2005). Samples that contained >10 shards per $0.5 \mathrm{~g}$ dry weight (dw) were re-sampled at higher resolution to isolate the position of the cryptotephra deposits to the nearest $1 \mathrm{~cm}$. A light-powered, polarizing microscope was employed to identify and count the glass shard concentrations. For geochemical analysis, samples were processed following the same methodology with the exception of the ashing step. Due to the low shard concentrations a micromanipulator was used to extract individual shards for geochemical analysis. Geochemical analyses of single 
glass shards were undertaken at the Tephra Analytical Unit at the University of Edinburgh using a Cameca SX100 wavelength dispersive spectrometer electronprobe micro analyser (WDS EPMA). All shards were analysed using the same operating conditions outlined in Hayward (2012). The geochemical data and secondary standards are in the supporting information (Table S1).

Tephra results for the early Holocene period from core LLO13 and the early- to midHolocene section from core LLO09 are shown in Fig. 2.

In addition to the contiguous sampling strategy, X-radiography images and XRF elemental data (including Ti, K, Ca, Fe and Al) were explored to try and determine whether any cryptotephras were observed in core LLO13. However no clear indicators were observed which is consistent with other similar studies (e.g., Kylander et al., 2012; Wulf et al., 2013).

\subsection{Radiocarbon dating}

Terrestrial plant macrofossils were sought for radiocarbon $\left({ }^{14} \mathrm{C}\right)$ dating, however these proved to be sparse. Below $580 \mathrm{~cm}$ in core LLO13 where the lithostratigraphy changes to gyttja, only aquatic macrofossils were preserved. The samples were chemically pre-treated at the Oxford Radiocarbon Accelerator Unit (ORAU) following the acid-base-acid (ABA) methodology outlined by Brock et al. (2010). ${ }^{14} \mathrm{C}$ dating was subsequently performed using a 2.5 MV HVEE tandem Accelerator Mass Spectrometry (AMS) system (Bronk Ramsey et al., 2004; Staff et al., 2014).

Two radiocarbon determinations had previously been obtained from the LLO05 core (Walker et al., 2009a). These were based on small samples of organic sediment and were dated by the AMS Radiocarbon Dating Laboratory, University of Lund, Sweden.

\subsection{Age-depth modelling}

Age-depth modelling was performed using the Bayesian statistical software OxCal (ver. 4.3; Bronk Ramsey, 2019), using the IntCal13 radiocarbon calibration curve (Reimer et al., 2013). A Poisson-process ('P_Sequence') deposition model was applied (Bronk Ramsey, 2008), using a model averaging approach ('variable k') to determine the optimum rigidity (variability allowed) in the modelled deposition rate (Bronk Ramsey and Lee, 2013). Two models were constructed in which different 
constraints were applied. In model A, all radiocarbon data (Table 1) were included (as 'R_Dates'), but the aquatic plant macrofossil samples and base insoluble ('humin') bulk sediment samples were modelled using the 'After' function in OxCal (to account for unquantified potential inbuilt ages as the result of hardwater reservoir effects). Outlier Analysis (Bronk Ramsey, 2009; Bronk Ramsey et al., 2010) was additionally applied to allow for the impact of potentially spurious data points to be down-weighted. Ages were derived for the depths of the tephra layers identified in this study using 'Date' functions in OxCal. Additionally, we included a constraint for the age of the Holocene onset, as determined at LLO by LOI, \% C and Ti (XRF) analysis, importing the NGRIP ice-core age of $11653 \pm 99$ a BP (maximum counting error; Rasmussen et al., 2006). This was necessary to increase chronological precision of the lower section of the model, enabling more robust testing of the likely geochemical correlations of the tephra layers identified at LLO with the published literature. Whilst we recognise that an assumption of perfect climatic synchroneity between south Wales and Greenland is unlikely (Brauer et al., 2014), it is generally considered that the transition into the Holocene was broadly synchronous globally (Walker et al., 2009b). We therefore propose that this is a reasonable assumption to include in our model, at least in terms of testing the likelihood of the inferred tephra attributions given the problems of radiocarbon dating experienced at this site.

The Holocene age constraint was not included within model B. Instead, model B included the preferred published age estimates of the three tentatively geochemically identified tephras as additional constraints. Model B therefore represents our best estimate of the chronology of LLO for the independent comparison of the palaeoenvironmental proxy data with sites from elsewhere. Both models are plotted against LLO13 core depth, with the two radiocarbon dates from core LLO05 and the four tephra layers obtained from core LLO09 transferred on to the LLO13 stratigraphy using linear interpolation between the tie-points identified in Fig. 2. The full coding of both models is given in the supplementary material (SI 2).

\section{Results}

3.1 Lithostratigraphy and sediment geochemistry

The sediment records in LLO09 and LLO13 both reached $820 \mathrm{~cm}$ depth but only the succession above $700 \mathrm{~cm}$ is presented here. Two distinct transitions are seen in the 
core sequences and reflected in the LOI and \% C values. The first, at $660 \mathrm{~cm}$ in LLO09 and $675 \mathrm{~cm}$ in LLO13 is characterised by a sudden increase in LOI and \% C and represent the transition from the Loch Lomond Stadial to the early Holocene. The second, at $550 \mathrm{~cm}$ in LLO09 and $575 \mathrm{~cm}$ in LLO13, is the change from limnic sediments to peat and is marked by the stabilisation of LOI and \% C values (Fig. 2).

\subsection{Radiocarbon dates}

The radiocarbon measurements for core LLO13 are outlined in Table 1, along with the two dates previously reported by Walker et al. (2009a) from core LLO05. The latter uppermost dates are included to provide useful constraints for the upper part of the profile. The five radiocarbon dates obtained from core LLO13 had sampling depths chosen based on the position of tephra deposits at $468 \mathrm{~cm}, 483 \mathrm{~cm}$ and 570 $\mathrm{cm}$, and the inferred climatic transition into the early Holocene. The upper two dates in core LLO13 were obtained from terrestrial plant macrofossils; however, the remaining dates were obtained from aquatic plant macrofossils $(576.5$ and $661.5 \mathrm{~cm})$ and bulk sediment $(679.5 \mathrm{~cm})$ due to the paucity of terrestrial material in the lower part of the sequence. As described above, radiocarbon determinations from these latter sample types would be expected to provide 'maximum ages', due to the potential incorporation of 'dead' and re-worked carbon contributing to an apparent ageing effect. The consequence of our modelling approach in accounting for this issue of inbuilt age (section 2.5) is that the output of the initial Bayesian age-depth model (A) is relatively imprecise (Fig. 4A). Despite this imprecision, however, the model output should still give accurate age estimates for the identified tephra deposits (below), which assist in the assessment of the potential geochemical correlations drawn.

\subsection{Tephra discoveries}

Details of the proposed tephra correlations found in this study are summarised in Table 2. Ten individual peaks of $>10$ shards per $\mathrm{g} d w$ were found in the Llyn Llech Owain record. Seven have been geochemically analysed which revealed four homogenous tephra deposits, two deposits with three chemical populations and one with two populations. In some cases where $>10$ shards were identified in the $5 \mathrm{~cm}$ resolution samples, no shards were identified during high resolution sampling (e.g., 
665-670 cm). Moreover, when shards were discovered in high resolution samples, shards were sometimes too sparse or not encountered at all during attempted extraction, and therefore no geochemical data were obtained (e.g., 595-594 cm). Several attempts were undertaken to isolate the widespread Vedde Ash, but no shards were found in the Loch Lomond Stadial sediments.

Tephra deposits are named here according to the basal sample depth and the core sequence found. All have a rhyolitic composition, with the exception of sample LLO13_580 which has a trachytic composition (Fig. 3A).

\subsubsection{Tephra LLO13 580: Fondi di Baia, Campi Flegrei, Italy (tentative correlation)}

Nineteen colourless glass shards were identified from this deposit and fourteen shards were analysed for their geochemical composition. Major element results reveal a heterogeneous composition with two populations, which are thought to have derived from separate eruptions. Population 1 consists of 9 trachytic shards with 62.11-63.14 wt\% $\mathrm{SiO}_{2}, 17.89-18.99$ wt $\% \mathrm{Al}_{2} \mathrm{O}_{3}, 2.07-2.43$ wt $\% \mathrm{CaO}$ and 8.71-9.06 $w t \% \mathrm{~K}_{2} \mathrm{O}$ (Fig. $3 \mathrm{~A}$ and $3 \mathrm{~B}$ ). This population has higher $\mathrm{CaO}$ values relative to $\mathrm{FeO}$, which discriminates it from Icelandic eruptions of dacitic and rhyolitic composition (Fig. 3A). Other volcanic sources from further afield such as Jan Mayen Island, the Azores, the Massif Central, the Eifel, the Cascades and Mediterranean sources were considered but, based on the high alkali and $\mathrm{Al}_{2} \mathrm{O}_{3}$ content, the most probable volcanic source was the Campi Flegrei (Italy). LLO13_580 is within the early Holocene section of the profile so comparisons were made with Campi Flegrei tephras of similar ages including the Fondi di Baia, Bacoli, Pigna San Nicol, St Martino, Sartania 1 and 2, and Pisani 3 tephras (Smith et al., 2011) (Fig. 3B). Based on the geochemical data, notably the $\mathrm{MgO}$ content, the most probable candidates are the Fondi di Baia and Bacoli tephras, although a slightly better overlap is observed with the former, which is most clearly seen in the Total Alkali Silica (TAS) plot (Fig. 3B). However, there are offsets in the alkalis and thus only a tentative correlation can be made at this stage. The Fondi di Baia Tephra is dated at 96959525 cal a BP (Smith et al., 2011), which is compatible with the early Holocene stratigraphic position of this deposit and in agreement (within 95.4\% uncertainty) with our LLO model A (Fig. 4A).

Population 2 consists of five rhyolitic shards and can be distinguished from population 1 based on $\mathrm{SiO}_{2}, \mathrm{Al}_{2} \mathrm{O}_{3}$ and $\mathrm{K}_{2} \mathrm{O}$ values. The TAS plot shows a similarity 
between population 2 and the Fosen and Hässeldalen Icelandic tephras (Fig. 3C). However, the $\mathrm{CaO}$ and $\mathrm{FeO}$ values prevent a firm correlation, suggesting population 2 to be a previously undocumented tephra of unknown origin.

\subsubsection{Tephra LLO09 516: Lairg A, Hekla, Iceland}

This tephra layer has a shard concentration of 16 colourless shards per $0.5 \mathrm{~g} \mathrm{dw}$. Four shards were geochemically analysed which revealed a homogenous rhyolitic composition with 76.52-77.37 wt\% $\mathrm{SiO}_{2}, 0.07-0.08$ wt\% $\mathrm{TiO}_{2}, 12.47-12.85$ wt\% $\mathrm{Al}_{2} \mathrm{O}_{3}$, and 2.82-3.05 wt\% $\mathrm{K}_{2} \mathrm{O}$. This tephra is located in the early-mid Holocene part of the LLO09 core and thus comparisons were again made with similarly aged tephras. Based on geochemical data, notably $\mathrm{SiO}_{2}, \mathrm{FeO}$ and $\mathrm{MgO}$ values, a correlation to the Icelandic Lairg A tephra is suggested (Fig. 3D). The Lairg A Tephra is dated at 6995-6805 cal a BP and is sourced from the Hekla volcano (Pilcher et al., 1996; Dugmore et al., 1995).

\subsubsection{Tephras LLO09 505, LLO13 468 and LLO13 483: Öræfajökull source, Iceland}

LLO09_505, LLO13_468 and LLO13_483 all contain <50 colourless shards per g dw. Only three shards were extracted and geochemically analysed from LLO09_505, which have a homogenous rhyolitic composition with 72.83-73.55 wt\% $\mathrm{SiO}_{2}, 3.42-$ 3.81 wt\% FeO, 1.03-1.14 wt\% $\mathrm{CaO}$ and 3.55-3.75 wt\% $\mathrm{K}_{2} \mathrm{O}$. Nineteen and five shards have been geochemically analysed from LLO13_468 and LLO13_483, respectively. All three deposits have indistinguishable chemical signatures (Fig. 3E) and, as such, the deposits in the different cores are likely to be related to each other. However, only one layer has been identified in the LLO09 core whereas LLO13_468 and LLO13_483 are found as distinct peaks in shard concentration, just $15 \mathrm{~cm}$ apart. It is possible that the two LLO13 deposits are the product of reworking, but the discrete nature of the shard peaks suggest that they originate from distinct primary input events. Moreover, any reworking would likely be manifest in a continual input of shards (Davies et al., 2007; Payne and Gehrels, 2010; Pyne O’Donnell, 2011; Davies, 2015).

Based on geochemical composition, notably the $\mathrm{CaO}, \mathrm{TiO}_{2}$ and $\mathrm{Al}_{2} \mathrm{O}_{3}$ values, the tephras show affinity to the Öræfajökull volcanic system (Fig. 3E). They are consistent with the composition of the Öræfajökull 1362 eruption but tephras in the 
LLO cores are clearly from a much earlier period. There is no evidence for older Öræfajökull eruptions of early-mid Holocene age recorded in the literature, which suggests that LLO09_505, LLO13_483 and LLO13_468 relate to newly identified eruption(s). An assumption is made that LLO09_505 correlates to the lower Öræfajökull tephra in LLO13, LLO13_483, rather than the later LLO13_468 tephra which is deemed the more likely scenario on stratigraphic grounds.

\subsubsection{Tephra LLO09 345: multiple sources}

LLO09_345 has a shard concentration of 44 colourless shards per $0.5 \mathrm{~g} \mathrm{dw}$.

Eighteen shards were geochemically analysed which revealed a heterogeneous sample with three separate rhyolitic populations. All three chemical populations are located within the Icelandic geochemical envelope (Fig. 3A). Notable differences in $\mathrm{K}_{2} \mathrm{O}, \mathrm{TiO}_{2}$ and $\mathrm{CaO}$ values are shown between the populations (Fig. 3F). Population 1 does not correlate with any known events as shown in the geochemical bivariate plots. Population 3 does show some similarity with the Microlite tephra based on $\mathrm{TiO}_{2}$ and $\mathrm{K}_{2} \mathrm{O}$ values, although $\mathrm{CaO}$ and $\mathrm{FeO}$ values differ, thus suggesting populations 1 and 3 may represent a new or previously unknown eruption. Population 2 correlates with data from the the Askja volcanic system (based on Askja-S data) (Fig. 3F). However, LLO09_345 is stratigraphically located in the mid Holocene part of the Llyn Llech Owain sequence and, assuming correct correlation of LLO09_516 to the Lairg A tephra, then this tephra deposit must be younger than 6995-6805 cal a BP. The stratigraphic position and the output from age model A (Table 3), does not support a correlation with the early Holocene Askja-S tephra (Fig. $3 F)$. Until recently, there have been no reported findings of other younger Askja-S type tephras; however, Guðmundsdóttir et al. (2016) have described a younger tephra (the Askja L) dated to approximately 9400 cal a BP (Striberger et al., 2012) and an Askja $\mathrm{H}$ tephra, dated to approximately 8850 cal a BP, has been identified by Jóhannsdóttir (2007). The Askja-L tephra reveals an identical chemical composition to Askja-S but the $\mathrm{Al}_{2} \mathrm{O}_{3}$ and $\mathrm{FeO}$ content for the latter differs from the Askja-S (Guðmundsdóttir et al., 2016). This discovery of a tephra with Askja affinities in Llyn Llech Owain may indicate the Askja volcano to have been more active during this period and that population 2 of tephra layer LLO09_345 may therefore represent a new or previously unknown Askja eruption. 


\subsubsection{Tephra LLO09 297: Aniakchak caldera-forming eruption (CFE) II Tephra,}

\section{Alaska (tentative correlation)}

LLO09_297 has a concentration of 22 colourless shards per $0.5 \mathrm{~g} \mathrm{dw}$. Only four shards were extracted and geochemically analysed which revealed a heterogeneous rhyolitic sample. Shards 1 and 2 are distinct based on their $\mathrm{TiO}_{2}$ and $\mathrm{FeO}$ values. Shards 3 and 4 are homogenous and can be distinguished from shards 1 and 2, notably by the $\mathrm{MgO}$ values. Geochemical comparisons were made with mid to late Holocene aged tephras. Shard 1 is chemically similar to population 2 in tephra deposit LLO09_345, which shows affinity to the Askja volcanic system (based on Askja-S data) (Fig. 3F). As noted above, however, there are no mid-Holocene aged Askja tephra deposits reported in the literature. Shard 2 shows geochemical affinity to the Lairg $A$ and the Hekla 4 tephras; however, based on the stratigraphy, a correlation with these tephras is unlikely (Fig. 3F). Shards 3 and 4 were also compared to Icelandic mid-Holocene tephras but a secure correlation was not established. A consideration of sources further afield suggests a possible correlation with the Aniakchak caldera-forming eruption (CFE) II Tephra (Pearce et al., 2004; Pyne O'Donnell et al., 2012). This tephra was sourced from the Aleutian Range, southwest Alaska and dated to $3572 \pm 4$ cal a BP (Pearce et al., 2017). This published age for the Aniakchak Tephra is in agreement (within 95.4\% uncertainty) with age model A from Llyn Llech Owain. Comparisons were also made with the White River Ash, Newberry Pumice and Mount Augustine Unit G (also from North America), but the $\mathrm{MgO}$ vs $\mathrm{TiO}_{2}$ bivariate plot strongly suggests a tentative correlation to the Aniakchak CFE II Tephra (Fig. 3G).

\section{Discussion}

Seven out of ten tephra deposits have been discovered and geochemically analysed in this study, although some of the deposits contain multiple populations. Only three tephras have been correlated, or tentatively correlated, with known eruptions (Table 2). All tephra deposits are cryptotephra in form and contain $<50$ shards per $0.5 \mathrm{~g} \mathrm{dw}$ and $<25$ shards $\mathrm{g} \mathrm{dw}$ for those proposed to be from far-travelled sources. The following sections provide a synthesis of the tephra discoveries in chronological order and the implications of the proposed correlations. 


\subsection{Fondi di Baia (LLO13 580)}

LLO13_580 has been tentatively correlated to the Fondi di Baia Tephra, sourced from Italy. This tephra is stratigraphically positioned in the early Holocene and dated to $9695-9525$ cal a BP (Smith et al., 2011). This eruption was not previously thought to have produced a widely distributed tephra with Smith et al. (2011) suggesting a north-westerly trajectory for the ash plume (Fig. 5A). The tentative discovery of the Fondi di Baia Tephra at Llyn Llech Owain, however, would increase its spatial distribution by a significant distance and is consistent with the dispersal pathway suggested by Smith et al (2011). If the correlation with Fondi di Baia is correct, this adds to the suggested tentative correlation between the GB4-45a tephra deposit in Garry Bog, Northern Ireland, with the Lipari Monte Pilato eruption (Plunkett and Pilcher, 2018). While questions may be raised as to whether an ash plume from Italy could travel towards the British Isles against the prevailing westerly winds, it is apparent that dust particles from the Sahara can be transported northwards to Europe and even the Arctic (Pitty, 1968; Stuut et al., 2009; Barkan and Alpert, 2010). That being so, it would be perfectly feasible for tephra to be borne northwards as well, given the same concomitant wind directions and similar synoptic conditions. As noted previously, the geochemical composition does not correlate perfectly, with slight differences seen in the $\mathrm{Na}_{2} \mathrm{O}$ and $\mathrm{K}_{2} \mathrm{O}$ values. Further geochemical analyses are needed to test this correlation.

\subsection{Lairg A (LLO09 516)}

Tephra deposit LLO09_516 has been suggested to correlate with the early-middle Holocene Lairg A eruption. If the attribution is correct, this discovery extends the spatial distribution of Lairg A further south and enables correlations with other Lairg A-bearing, sites including Claraghmore bog and lake (Northern Ireland), Malham Moss (northern England), Degerö Stormyr (northern Sweden) and Jardelunder Moor (northern Germany) (van den Bogaard and Schmincke, 2002; Watson et al., 2016; Fig. 5A). Further geochemical analyses are required, however, to provide a more robust correlation.

\subsection{Aniakchak CFE II (LLO09 297)}


Tephra deposit LLO09_297 has been tentatively correlated with the Aniakchak CFE II Tephra sourced from the caldera-forming eruption of Aniakchak in the Aleutian Range, southwest Alaska. Although only two analyses were made, the geochemical composition firmly correlates with the Aniakchak CFE II Tephra. This eruption of the Aniakchak volcano is thought to have produced a very widely dispersed tephra, with an estimated eruptive volume of $>50 \mathrm{~km}^{3}$ (Miller and Smith, 1987). This tephra has been recognised over a wide area, being identified in the Prospector-Russell Col ice core, St Elias Mountains, north-west Canada (Zdanowicz et al., 2014); in a sediment record from Newfoundland, eastern Canada (Pyne-O'Donnell et al., 2012); in a marine core on the SE Greenland shelf (Jennings et al., 2014); in the Arctic ocean (Pearce et al., 2017) and in the GRIP ice core in Greenland (Pearce et al., 2004; Coulter et al., 2012; Fig. 5B). Until recently, no findings have been reported as far east as mainland Britain, although Plunkett and Pilcher (2018) have identified the Aniakchak tephra in Garry Bog, Northern Ireland, after re-assessing the geochemistry of deposit GB4-182b (first analysed in the 1990s by Hall and Pilcher, 2002). This finding lends support to the identification of the Aniakchak tephra in south Wales and is consistent with other examples of trans-Atlantic transport of ash. The White River Ash, originating from Mount Churchill (Alaska), is found in a number of northern European sites including as far east as Poland (Jensen et al., 2014; Watson et al., 2017a), while the Glacier Peak G and B Tephra, originating from the Cascades (NW America), has also been discovered at Finglas River, SW Ireland, (Turney, 1998; Timms et al., 2019).

The dating of the Aniakchak CFE II Tephra has proved to be contentious, as the age estimate based on radiocarbon dating conflicts with the Greenland ice core age (Davies et al., 2016). However, Pearce et al. (2017) have suggested that after taking account of the offsets between the IntCal13 radiocarbon timescale and the GICC05 ice-core timescale (Adolphi and Muscheler, 2016), a closer agreement is evident and a revised age $3572 \pm 4$ cal a BP can now be assigned to the Aniakchak CFE II Tephra. Along with providing a precise age estimate for this part of the Llyn Llech Owain record, this tephra provides a direct isochronous link with the Greenland ice core record and to the other tephra bearing sites noted above.

\subsection{Age-Depth Model B (including tephra constraints)}


By incorporating the current best age estimates from the literature for the three tentatively identified tephras (above), it is now possible to improve the precision and, assuming correct tephra correlations, accuracy of the age-depth model for Llyn Llech Owain (Fig. 4B). As noted in section 2.5, model B does not require the inclusion of the Holocene onset inferred from the Greenland ice-cores (as was necessary for model A; Fig. 4A). The improved age-depth model B also provides updated ages for the other, as yet, unknown tephra deposits identified within the LLO sequence, as given in Table 2.

\subsection{Unknown tephra deposits - new eruptions?}

Four tephra deposits have not been correlated to any known eruptions and may represent new or previously undocumented eruptions. These include LLO13_483, LLO13_467, LLO09_505 and LLO09_345, in addition to population 2 of LLO13_580 and shard 1 and 2 in LLO09_297. New age estimates for these deposits, derived from age model B, are presented in Table 3. The presently unknown tephra deposits demonstrate that our current understanding of widespread tephra deposits is incomplete, even for the intensively studied Holocene period and demonstrates the insight gained from investigating sites in distal locations.

All uncorrelated tephra deposits have rhyolitic compositions which are typically produced during highly explosive eruptions and are often associated with long-range ash dispersal (Larsen and Eiríksson, 2008). Reference geochemical tephra datasets and regional tephrostratigraphy review papers for Europe provide extensive databases for tephra identification (e.g., RESET - Bronk Ramsey et al., 2015; Davies et al., 2012: Lawson et al., 2012; Blockley et al., 2014), although these are continuously being updated with unknown eruptions (e.g., Lane et al., 2015; Jones et al., 2018). Reference datasets and tephrostratigraphy records for volcanic regions further afield, and from which some of these uncorrelated deposits may have originated, may not be as complete, which provides a major constraint on current correlations.

5. Conclusions 
For a number of years, very little evidence had been found for tephra preservation in Welsh sites. However, the new findings from Llyn Llech Owain and other recent studies (Watson et al., 2017b and Jones et al., 2017), demonstrate that tephra deposits are indeed present in sites in Wales, and that these may well facilitate linkages far beyond NW Europe.

Seven tephra deposits have been discovered from the early- to mid-Holocene part of the Llyn Llech Owain sediment record. Three have been correlated, or tentatively correlated, with known eruptions: LLO13_580 (Fondi di Baia Tephra), LLO09_516 (Lairg A) and LLO09_297 (Aniakchak CFE II). The remaining four deposits have not yet been correlated with previously published tephras and are considered to represent previously undocumented eruptive events. The tephra record uncovered highlights the potential for sites at more southerly and westerly locations in NW Europe to act as repositories for ash from several volcanic regions. Furthermore, these findings mark Llyn Llech Owain as an important site, not only in Britain, but in the wider North Atlantic province, as it contains tephras originating from three different volcanic regions (North America, Italy and Iceland), thereby enabling intersite correlations at not only regional but, more importantly, at continental and hemispherical scales. 


\section{Acknowledgements}

This work was conducted as part of a PhD study, supported by the Coleg Cymraeg Cenedlaethol. Radiocarbon dates for this study were analysed by the NERC Radiocarbon Dating Facility (NRCF) funding (Radiocarbon Analysis Allocation Number 1882.0415).

We would like to thank Natural Resources Wales and Llyn Llech Owain Country Park. Thanks to Dr Chris Hayward for his assistance with the use of the electron microprobe at the Tephrochronology Analytical Unit, University of Edinburgh. Thanks also to Hannah Sams, Idris Birch, Tom Brain, Dai Brain, Gareth James (Swansea University) and the Swansea Tephra group for laboratory/field assistance and advice. RAS was supported by a Leverhulme Trust Early Career Fellowship (ECF2015-396). Two anonymous reviewers are thanked for their constructive comments. 
References

Abbott PM, Griggs AJ, Bourne AJ et al. 2018. Tracing marine cryptotephras in the North Atlantic during the last glacial period: improving the North Atlantic marine tephrostratigraphic framework. Quaternary Science Reviews 189: 169-186.

Adolphi F, Muscheler R. 2016. Synchronizing the Greenland ice core and radiocarbon timescales over the Holocene-Bayesian wiggle-matching of cosmogenic radionuclide records. Climate of the Past 12: 15-30.

Barber KE, Maddy D, Rose N et al. 2000. Replicated proxy-climate signals over the last 2000 yr from two distant UK peat bogs: new evidence for regional palaeoclimate teleconnections. Quaternary Science Reviews 19: 481-487.

Barkan J, Alpert P. 2010. Synoptic analysis of a rare event of Saharan dust reaching the Arctic region. Weather 65: 208-211.

Bergman J, Wastegård S, Hammarlund D et al. 2004. Holocene tephra horizons at Klocka Bog, west-central Sweden: aspects of reproducibility in subarctic peat deposits. Journal of Quaternary Science 19: 241-249.

Blockley SPE, Bourne AJ, Brauer A et al. 2014. Tephrochronology and the extended intimate (integration of ice-core, marine and terrestrial records) event stratigraphy 8128 ka b2k. Quaternary Science Reviews 106: 88-100.

Bourne AJ, Cook E, Abbott PM et al. 2015. A tephra lattice for Greenland and a reconstruction of volcanic events spanning 25-45 ka b2k. Quaternary Science Reviews 118: 122-141.

Bourne AJ, Abbott PM, Albert PG et al. 2016. Underestimated risks of recurrent longrange ash dispersal from northern Pacific Arc volcanoes. Scientific Reports 6: 1-8.

Brauer A, Hajdas I, Blockley SP et al. 2014. The importance of independent chronology in integrating records of past climate change for the 60-8 ka INTIMATE time interval. Quaternary Science Reviews 106: 47-66.

Brock F, Higham T, Ditchfield P et al. 2010. Current pretreatment methods for AMS radiocarbon dating at the Oxford Radiocarbon Accelerator Unit (ORAU).

Radiocarbon 52: 103-112.

Bronk Ramsey C, Higham T, Leach P. 2004. Towards high-precision AMS: progress and limitations. Radiocarbon 46: 17-24.

Bronk Ramsey C. 2019. OxCal Project, Version 4.3. https://c14.arch.ox.ac.uk/oxcal/OxCal.html.

Bronk Ramsey C. 2008. Deposition models for chronological records. Quaternary Science Reviews 27: 42-60.

Bronk Ramsey CB. 2009. Dealing with outliers and offsets in radiocarbon dating. Radiocarbon 51: 1023-1045. 
Bronk Ramsey CB, Dee M, Lee S et al. 2010. Developments in the calibration and modeling of radiocarbon dates. Radiocarbon 52: 953-961.

Bronk Ramsey C, Lee S. 2013. Recent and Planned Developments of the Program OxCal. Radiocarbon 55: 720-730.

Bronk Ramsey B, Albert PG, Blockley SPE et al. 2015. Improved age estimates for key Late Quaternary European tephra horizons in the RESET lattice. Quaternary Science Reviews 118: 18-32.

Buckley SL, Walker MJC. 2002. A mid-Flandrian tephra horizon, Cambrian Mountains, west Wales. Quaternary Newsletter 96: 5-11.

Chambers FM, Daniell JRG, Hunt JB et al. 2004. Tephrostratigraphy of An Loch Mor, Inis Oirr, western Ireland: implications for Holocene tephrochronology in the northeastern Atlantic region. The Holocene 14: 703-720.

Cook E, Portnyagin M, Ponomareva V et al. 2018. First identification of cryptotephra from the Kamchatka Peninsula in a Greenland ice core: Implications of a widespread marker deposit that links Greenland to the Pacific northwest. Quaternary Science Reviews 181: 200-206.

Coulter SE, Pilcher JR, Plunkett G et al. 2012. Holocene tephras highlight complexity of volcanic signals in Greenland ice cores. Journal of Geophysical Research Atmospheres 117: D21303.

Croudace IW, Rindby A, Rothwell RG. 2006. ITRAX: description and evaluation of a new multi-function X-ray core scanner. Geological Society London Special Publications 267: 51-63.

Davies LJ, Jensen BJ, Froese DG et al. 2016. Late Pleistocene and Holocene tephrostratigraphy of interior Alaska and Yukon: Key beds and chronologies over the past 30,000 years. Quaternary Science Reviews 146: 28-53.

Davies SM, Branch NP, Lowe JJ et al. 2002. Towards a European tephrochronological framework for termination 1 and the early holocene. Philosophical Transactions of the Royal Society a-Mathematical Physical and Engineering Sciences 360: 767-802.

Davies SM, Hoek WZ, Bohncke SJP et al. 2005. Detection of Lateglacial distal tephra layers in the Netherlands. Boreas 34: 123-135.

Davies SM, Elmquist M, Bergman J et al. 2007. Cryptotephra sedimentation processes within two lacustrine sequences from west central Sweden. The Holocene 17: 319-330.

Davies SM, Abbott PM, Pearce NJG et al. 2012. Integrating the INTIMATE records using tephrochronology: rising to the challenge. Quaternary Science Reviews 36: 1127.

Davies SM, 2015. Cryptotephras: the revolution in correlation and precision dating. Journal of Quaternary Science 30: 114-130. 
Dugmore AJ. 1989. Icelandic volcanic ash in Scotland. The Scottish Geographical Magazine 105: 168-172.

Dugmore AJ, Larsen G, Newton AJ. 1995. Seven tephra isochrones in Scotland. The Holocene 5: 257-266.

Griggs AJ, Davies SM, Abbott PM et al. 2014. Optimising the use of marine tephrochronology in the North Atlantic: a detailed investigation of the Faroe Marine Ash zones II, III and IV. Quaternary Science Reviews 106: 122-139.

Guðmundsdóttir ER, Larsen G, Björck S et al. 2016. A new high-resolution Holocene tephra stratigraphy in eastern Iceland: Improving the Icelandic and North Atlantic tephrochronology. Quaternary Science Reviews 150: 234-249.

Hall VA, Pilcher JR, McCormac FG. 1994. Icelandic volcanic ash and the midHolocene Scots pine (Pinus sylvestris) decline in the north of Ireland: no correlation. The Holocene 4: 79-83.

Hall VA, Pilcher JR. 2002. Late-Quaternary Icelandic tephras in Ireland and Great Britain: detection, characterization and usefulness. The Holocene 12: 223-230.

Hayward C. 2012. High spatial resolution electron probe microanalysis of tephras and melt inclusions without beam-induced chemical modification. The Holocene 22: 119-125.

Heiri O, Lotter AF, Lemcke G. 2001. Loss on ignition as a method for estimating organic and carbonate content in sediments: reproducibility and comparability of results. Journal of Paleolimnology 25: 101-110.

Jennings A, Thordarson T, Zalzal K et al. 2014. Holocene tephra from Iceland and Alaska in SE Greenland shelf sediments. Geological Society London Special Publications 398: 157-193.

Jensen BJ, Pyne-O'Donnell S, Plunkett G et al. 2014. Transatlantic distribution of the Alaskan white river ash. Geology 42: 875-878.

Jóhannsdóttir GE. 2007. Mid Holocene to late glacial tephrochronology in West Iceland as revealed in three lacustrine environments. M.S. thesis, University of Iceland, Reykjavik.

Jones G, Davies SM, Farr GJ et al. 2017. Identification of the Askja-S Tephra in a rare turlough record from Pant-y-Llyn, south Wales. Proceedings of the Geologists' Association 128: 523-530.

Jones G, Lane CS, Brauer A et al. 2018. The Lateglacial to early Holocene tephrochronological record from Lake Hämelsee, Germany: a key site within the European tephra framework. Boreas 47: 28-40.

Kaufman DS, Jensen BJL, Reyes AV et al. 2012. Late Quaternary tephrostratigraphy, Ahklun Mountains, SW Alaska. Journal of Quaternary Science 27: 344-359. 
Kearney R, Albert PG, Staff RA et al. 2018.Ultra-distal fine ash occurrences of the Icelandic Askja-S Plinian eruption deposits in Southern Carpathian lakes: new age constraints on a continental scale tephrostratigraphic marker. Quaternary Science Reviews 188: 174-182.

Kelly TJ, Hardiman M, Lovelady M et al. 2017. Scottish early Holocene vegetation dynamics based on pollen and tephra records from Inverlair and Loch Etteridge, Inverness-shire. Proceedings of the Geologists' Association 128: 125-135.

Kylander ME, Lind EM, Wastegård S et al. 2012. Recommendations for using XRF core scanning as a tool in tephrochronology. The Holocene 22: 371-375.

Lane CS, Brauer A, Martín-Puertas C et al. 2015. The Late Quaternary tephrostratigraphy of annually laminated sediments from Meerfelder Maar, Germany. Quaternary Science Reviews 122: 192-206.

Langdon PG, Barber KE, Hughes PDM. 2003. A 7500-year peat-based palaeoclimatic reconstruction and evidence for an 1100-year cyclicity in bog surface wetness from Temple Hill Moss, Pentland Hills, southeast Scotland. Quaternary Science Reviews 22: 259-274.

Larsen G, Eiríksson J. 2008. Late Quaternary terrestrial tephrochronology of Iceland - frequency of explosive eruptions, type and volume of tephra deposits. Journal of Quaternary Science 23: 109-120.

Larsson SA, Wastegård S. 2018. The Laacher See Tephra discovered in southernmost Sweden. Journal of Quaternary Science 33: 477-481.

Lawson IT, Swindles GT, Plunkett G et al. 2012. The spatial distribution of Holocene cryptotephras in north-west Europe since $7 \mathrm{ka}$ : implications for understanding ash fall events from Icelandic eruptions. Quaternary Science Reviews 41: 57-66.

Le Bas MJ, Le Maitre R, Streckeisen A et al. 1986. A chemical classification of volcanic rocks based on the total alkali-silica diagram. Journal of petrology 27: 745750.

Matthews IP, Birks HH, Bourne AJ et al. 2011. New age estimates and climatostratigraphic correlations for the Borrobol and Penifiler Tephras: evidence from Abernethy Forest, Scotland. Journal of Quaternary Science 26: 247-252.

Miller TP, Smith RL. 1987. Late Quaternary caldera-forming eruptions in the eastern Aleutian arc, Alaska. Geology 15: 434-438.

Payne R. Gehrels M. 2010. The formation of tephra layers in peatlands: an experimental approach. Catena 81: 12-23.

Pearce C, Varhelyi A, Wastegård S et al. 2017. The 3.6 ka Aniakchak tephra in the Arctic Ocean: a constraint on the Holocene radiocarbon reservoir age in the Chukchi Sea. Climate of the Past 13: 303-316. 
Pearce NJG, Westgate JA, Preece SJ et al. 2004. Identification of Aniakchak (Alaska) tephra in Greenland ice core challenges the 1645 BC date for Minoan eruption of Santorini. Geochemistry, Geophysics, Geosystems 5: 1-10.

Persson C. 1966. Försök till tefrokronologisk datering av några svenska torvmossar. Geologiska Foereningan i Stockholm Foerhandlingar 88: 361-395.

Pilcher J, Bradley RS, Francus P et al. 2005. A Holocene tephra record from the Lofoten Islands, arctic Norway. Boreas 34: 136-156.

Pilcher JR, Hall V, McCormac FG. 1996. An outline tephrochronology for the Holocene of the north of Ireland. Journal of Quaternary Science 11: 485-494.

Pilcher JR, Hall VA. 1992. Towards a tephrochronology for the Holocene of the north of Ireland. The Holocene 2: 255-259.

Pitty AF. 1968. Particle size of the Saharan dust which fell in Britain in July 1968. Nature 220: 364.

Plunkett GM. 2006. Tephra-linked peat humification records from Irish ombrotrophic bogs question nature of solar forcing at 850 cal. yr BC. Journal of Quaternary Science 21: 9-16.

Plunkett GM, Pilcher JR. 2018. Defining the potential source region of volcanic ash in northwest Europe during the Mid-to Late Holocene. Earth-Science Reviews 179: 20-37.

Pyne-O'Donnell SDF. 2011. The taphonomy of Last Glacial-Interglacial Transition (LGIT) distal volcanic ash in small Scottish lakes. Boreas 40: 131-145.

Pyne-O'Donnell SDF, Hughes PD, Froese DG et al. 2012. High-precision ultra-distal Holocene tephrochronology in North America. Quaternary Science Reviews 52: 611.

Rasmussen SO, Andersen KK, Svensson AM et al. 2006. A new Greenland ice core chronology for the last glacial termination. Journal of Geophysical Research: Atmospheres 111.

Reimer PJ, Bard E, Bayliss A et al. 2013. IntCal13 and Marine13 radiocarbon age calibration curves 0-50,000 years cal BP. Radiocarbon 55: 1869-1887.

Smith VC, Isaia R, Pearce NJG. 2011. Tephrostratigraphy and glass compositions of post-15 kyr Campi Flegrei eruptions: implications for eruption history and chronostratigraphic markers. Quaternary Science Reviews 30: 3638-3660.

Staff RA, Reynard L, Brock F et al. 2014. Wood pretreatment protocols and measurement of tree-ring standards at the Oxford Radiocarbon Accelerator Unit (ORAU). Radiocarbon 56: 709-715.

Striberger J, Björck S, Holmgren S et al. 2012. The sediments of Lake Lögurinn-A unique proxy record of Holocene glacial meltwater variability in eastern Iceland. Quaternary Science Reviews 38: 76-88. 
Stuut JB, Smalley I, O'Hara-Dhand K. 2009. Aeolian dust in Europe: African sources and European deposits. Quaternary International 198: 234-245.

Timms RGO, Matthews IP, Palmer AP et al. 2016. A high-resolution tephrostratigraphy from Quoyloo Meadow, Orkney, Scotland: Implications for the tephrostratigraphy of NW Europe during the Last Glacial-Interglacial Transition. Quaternary Geochronology 40: 67-81.

Timms RGO, Matthews IP, Palmer AP et al. 2018. Toward a tephrostratigraphic framework for the British Isles: A Last Glacial to Interglacial Transition (LGIT c. 16-8 ka) case study from Crudale Meadow, Orkney. Quaternary Geochronology 46: 2844.

Timms RGO, Matthews IP, Lowe JJ et al. 2019. Establishing tephrostratigraphic frameworks to aid the study of abrupt climatic and glacial transitions: a case study of the Last Glacial-Interglacial Transition in the British Isles (c. 16-8 ka BP). EarthScience Reviews 192: 34-64.

Turney CSM. 1998. Extraction of rhyolitic component of Vedde microtephra from minerogenic lake sediments. Journal of Paleolimnology 19: 199-206.

Turney CSM, Den Burg KV, Wastegård S et al. 2006. North European last glacialinterglacial transition (LGIT; 15-9 ka) tephrochronology: extended limits and new events. Journal of Quaternary Science: Published for the Quaternary Research Association 21: 335-345.

van den Bogaard P, Schmincke HU. 2002. Linking the North Atlantic to central Europe: a high-resolution Holocene tephrochronological record from northern Germany. Journal of Quaternary Science 17: 3-20.

van der Bilt WG, Lane CS, Bakke J. 2017. Ultra-distal Kamchatkan ash on Arctic Svalbard: Towards hemispheric cryptotephra correlation. Quaternary Science Reviews 164: 230-235.

Vorren KD, Blaauw M, Wastegård S et al. 2007. High-resolution stratigraphy of the northernmost concentric raised bog in Europe: Sellevollmyra, Andøya, northern Norway. Boreas 36: 253-277.

Walker MJC, Davies S, Hall J et al. 2009a. A Preliminary Palaeoecological record from Llyn Llech Owain, near Gorslas, Carmarthenshire. Archeology in Wales 49: 5358.

Walker MJC, Jones S. 2006. Llyn Llech Owain: a Pollen Analytical Assessment. Report for Carmarthenshire County Council, University of Wales, Lampeter.

Walker MJC, Johnsen S, Rasmussen SO et al. 2009b. Formal definition and dating of the GSSP (Global Stratotype Section and Point) for the base of the Holocene using the Greenland NGRIP ice core, and selected auxiliary records. Journal of Quaternary Science: Published for the Quaternary Research Association 24: 3-17. 
Waters CN, Waters RA, Barclay WJ et al. 2009. A lithostratigraphical framework for the Carboniferous successions of southern Great Britain (Onshore). British Geological Survey.

Watson EJ, Swindles GT, Lawson IT et al. 2016. Do peatlands or lakes provide the most comprehensive distal tephra records? Quaternary Science Reviews 139: 110128.

Watson EJ, Kołaczek P, Słowiński M et al. 2017a. First discovery of Holocene Alaskan and Icelandic tephra in Polish peatlands. Journal of Quaternary Science 32: 457-462.

Watson EJ, Swindles GT, Lawson IT et al. 2017b. The presence of Holocene cryptotephra in Wales and southern England. Journal of Quaternary Science 32: 493-500.

Wulf S, Ott F, Słowiński M, et al. 2013. Tracing the Laacher See Tephra in the varved sediment record of the Trzechowskie palaeolake in central Northern Poland. Quaternary Science Reviews 76: 129-139.

Wulf S, Dräger N, Ott F, et al. 2016. Holocene tephrostratigraphy of varved sediment records from Lakes Tiefer See (NE Germany) and Czechowskie (N Poland). Quaternary Science Reviews 132: 1-14.

Zdanowicz C, Fisher D, Bourgeois J et al. 2014. Ice cores from the St. Elias Mountains, Yukon, Canada: their significance for climate, atmospheric composition and volcanism in the North Pacific region. Arctic 67: 35-57. 
Table 1. Radiocarbon determinations and un-modelled calibrated age ranges for Llyn Llech Owain. Age estimates are calibrated against the IntCal13 calibration curve (Reimer et al., 2013). The upper two dates are from the LLO05 core (Walker et al., 2009a) and the dates from core LLO13 are derived from this study.

\begin{tabular}{|c|c|c|c|c|c|c|}
\hline Depth $(\mathrm{cm})$ & Lab code & $\delta^{13} \mathrm{C} \%$ (VPDB) & $\begin{array}{l}\text { Conventional } \\
\text { Radiocarbon } \\
\text { age }\left({ }^{14} \mathrm{C} \text { a BP }\right)\end{array}$ & $\begin{array}{c} \pm 1 \sigma \\
\text { uncertainty }\end{array}$ & $\begin{array}{l}\text { Calibrated age range } \\
\quad(95.4 \%)(a \mathrm{BP})\end{array}$ & Dated material \\
\hline \multicolumn{7}{|c|}{ Core LLO05 } \\
\hline 141 & LuS 7106 & & 3380 & 45 & $3816-3481$ & organic sediment \\
\hline 259 & LuS 7107 & & 4725 & 50 & $5585-5322$ & organic sediment \\
\hline \multicolumn{7}{|c|}{ Core LL013 } \\
\hline 467.5 & OxA- 33159 & -26.5 & 8215 & 40 & $9295-9029$ & wood fragments \\
\hline 482.5 & OxA- 33160 & -27.8 & 9225 & 45 & $10511-10254$ & $\begin{array}{l}\text { Betula leaf } \\
\text { fragments }\end{array}$ \\
\hline 576.5 & OxA- 32973 & -24.1 & 8190 & 45 & $9279-9020$ & $\begin{array}{c}\text { Potamogeton } \\
\text { seeds (aquatic) }\end{array}$ \\
\hline 661.5 & OxA- 32974 & -16.6 & 10210 & 50 & $12119-11719$ & $\begin{array}{l}\text { Ceratophyllum } \\
\text { seeds (aquatic) }\end{array}$ \\
\hline 679.5 & OxA- 33324 & -21.8 & 13215 & 75 & $16132-15639$ & $\begin{array}{l}\text { bulk sediment } \\
\text { (humin fraction) }\end{array}$ \\
\hline
\end{tabular}


Table 2. Shard concentrations, number of shards geochemically analysed, degree of homogeneity, proposed correlation, preferred age estimate. See Fig. 5 for geographical distribution of Fondi di Baia, Lairg A and Aniakchack CFE II.

\begin{tabular}{|c|c|c|c|c|c|c|}
\hline $\begin{array}{l}\text { Tephra } \\
\text { deposit }\end{array}$ & $\begin{array}{l}\text { Shards } \\
\text { (per } 0.5 \\
\mathrm{~g} \mathrm{dw})\end{array}$ & $\begin{array}{l}\text { Shards } \\
\text { analysed }\end{array}$ & Homogenous? & Proposed correlation & $\begin{array}{c}\text { Age } \\
\text { estimate } \\
\text { (cal a BP) }\end{array}$ & Reference \\
\hline LLO13_580 & 19 & 14 & 2 populations & $\begin{array}{c}\text { Fondi di Baia Tephra } \\
\text { (population 1) }\end{array}$ & $9695-9525$ & $\begin{array}{c}\text { Smith et al., } \\
2011\end{array}$ \\
\hline LLO13_483 & 45 & 19 & yes & unknown & & \\
\hline LLO13_468 & 46 & 5 & yes & unknown & & \\
\hline LLO09_516 & 16 & 4 & yes & Lairg A Tephra & $6995-6805$ & $\begin{array}{c}\text { Pilcher et al., } \\
1996\end{array}$ \\
\hline LLO09_505 & 28 & 3 & yes & unknown & & \\
\hline LLO09_345 & 44 & 18 & 3 populations & unknown & & \\
\hline LLO09_297 & 22 & 4 & $\begin{array}{c}1 \text { population ( } 2 \\
\text { outliers) }\end{array}$ & $\begin{array}{c}\text { Aniakchak CFE II } \\
\text { Tephra (main } \\
\text { population) }\end{array}$ & $3572 \pm 4$ & $\begin{array}{c}\text { Pearce et al., } \\
2017\end{array}$ \\
\hline
\end{tabular}


Table 3. Age range outputs from models A and B for the tephra deposits discovered in the Llyn Llech Owain sediment cores. Age estimates for the tentatively correlated tephras are from: ${ }^{a}$ - Pearce et al., 2017; ${ }^{\text {b }}$ - Pilcher et al., 1996; ' - Smith et al., 2011.

\begin{tabular}{|ccccc|}
\hline Tephra deposit & \multicolumn{2}{c}{ Model A } & \multicolumn{2}{c|}{ Model B } \\
& $\begin{array}{c}\text { age range cal a } \\
\text { BP (95.4\%) }\end{array}$ & $\begin{array}{c}\text { age range cal a } \\
\text { BP (68.2\%) }\end{array}$ & $\begin{array}{c}\text { age range cal a } \\
\text { BP (95.4\%) }\end{array}$ & $\begin{array}{c}\text { age range cal a } \\
\text { BP (68.2\%) }\end{array}$ \\
\hline LLO09_297 & $5562-2957$ & $5417-4252$ & $3580-3564$ a & $3576-3568$ a \\
LLO09_345 & $7506-3737$ & $6522-4922$ & $5195-3572$ & $4528-3701$ \\
LLO13_468 & $9416-7021$ & $9279-9034$ & $6952-5657$ & $6874-6250$ \\
LLO13_483 \& & $10568-7391$ & $10503-9130$ & $6986-6015$ & $6931-6526$ \\
LLO09_505 & $11033-7898$ & $10720-8711$ & $6995-6805^{\mathrm{b}}$ & $6947-6852$ b \\
LLO09_516 & $11579-8848$ & $11301-9972$ & $9695-9525^{\mathrm{c}}$ & $9653-9567^{\mathrm{c}}$ \\
\hline LLO13_580 & 1130 & & &
\end{tabular}


Figure 1. Location of Llyn Llech Owain, bedrock geology and coring location.

Figure 2. Lithostratigraphy, sediment geochemistry profiles (LOI for core LLO09 and $\% \mathrm{C}$ and $\mathrm{Ti}$ (XRF) for core LLO13), calibrated radiocarbon age ranges (95.4\%) (a $\mathrm{BP}$ ) and tephra shard concentrations (5-and1-cm resolution) from core LLO09 and LLO13 for Llyn Llech Owain. ------ denotes the core correlation depths (as discussed in the text).

Figure 3. A-G - A) The full data set for this study plotted using the Total Alkali Silica classification of Le Bas et al. (1986) and a FeO vs CaO bivariate plot showing the compositions of glass shard analyses in relation to the Icelandic volcanic field (comprised of all glass analyses of dacitic and rhyolitic tephra deposits from Iceland in the RESET database - Bronk Ramsey et al., 2015) (modified from Bourne et al., 2016). B-G Selected bivariate plots showing tephra glass shard major element compositions for all tephra deposits found in this study. Reference envelopes are based on data from the RESET database. The geochemical data discussed in the text and shown in the bivariate plots are normalized. The raw data are available in the supporting information (Table SI 1).

Figure 4. Age-depth models generated for Llyn Llech Owain: (model A) independent of the proposed tephra correlations; (model B) incorporating the best current age estimates of the three identified tephra layers. The darker and lighter blue probability envelopes represent the $68.2 \%$ and $95.4 \%$ confidence intervals, respectively. The coloured text represents: brown - base insoluble ('humin') bulk sediment samples, green - terrestrial plant macrofossils, blue - aquatic plant macrofossils, purple Holocene onset chronological control point (as determined by LOI, \% C and Ti (XRF) analysis), orange - cryptotephra deposits, red - age estimate for the tephra deposits.

Figure 5. A) Spatial distribution map for the Lairg A Tephra and Fondi di Baia Tephra. Modified from Lawson et al. (2012) and Watson et al. (2016). 1 - Sellevoll (Vorren et al., 2007), 2 - Borge (Pilcher et al., 2005), 3 - Klocka Bog (Bergman et al., 2004), 4 - Degerö Stormyr (Watson et al., 2016), 5 - Jardelunde (van den Bogaard and Schminckle, 2002), 6 - Grambow (van den Bogaard and Schminckle, 2002), 7 Lairg (Dugmore et al., 1995), 8 - Temple Hill Moss (Langdon et al., 2003), 9 Malham Moss (Watson et al., 2016), 10 - Garry Bog (Hall et al., 1994), 11 Fallahogy (Barber et al., 2000), 12 - Ballynahone (Pilcher et al., 1996), 13 - Sluggan (Hall et al., 1994), 14 - Claraghmore (Watson et al., 2016), 15 - An Loch Mór (Chambers et al., 2004),16 - Moyreen (Plunkett, 2006). B) Spatial distribution map for the Aniakchak Tephra. 1 - Zagoskin Lake (Kaufman et al., 2012), 2 - Chukchi Sea (Pearce et al., 2017), 3 - GRIP (Pearce et al., 2004), 4 - SE Greenland shelf 
(Jennings et al., 2014), 5 - Newfoundland (Pyne O'Donnell et al., 2012), 6 - Garry Bog (Plunkett \& Pilcher, 2018).

Supporting information

Table S1. Geochemical data for cryptotephra deposits and Lipari and BCR2g secondary standards data for this study.

S2. OxCal age-depth model coding. 


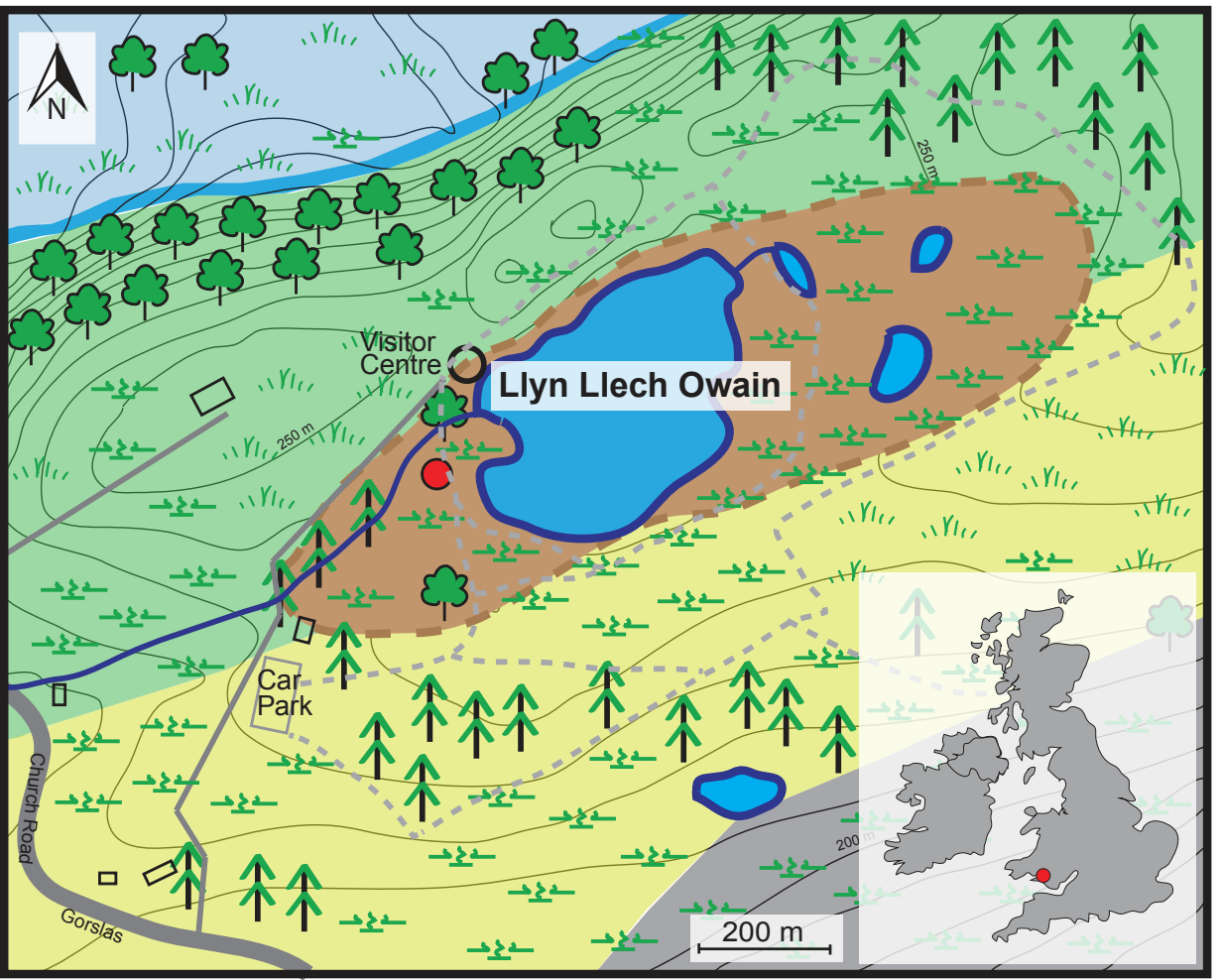

$\begin{array}{|lll|}\begin{array}{l}\text { Penderyn Oolite } \\ \text { Member }\end{array} & \begin{array}{l}\text { Bishopston Mudstone } \\ \text { Formation }\end{array} & \begin{array}{l}\text { Oxwich Head } \\ \text { Limestone Formation } \\ \text { South Wales Lower } \\ \text { Coal Measures Formation }\end{array} \\ \text { Core location } & \begin{array}{l}\text { Twrch Sandstone } \\ \text { Formation }\end{array} \\ \text { Ponds / Streams } & \text { Road } & \text { Peat deposits }\end{array}$




\section{Core LLO09}

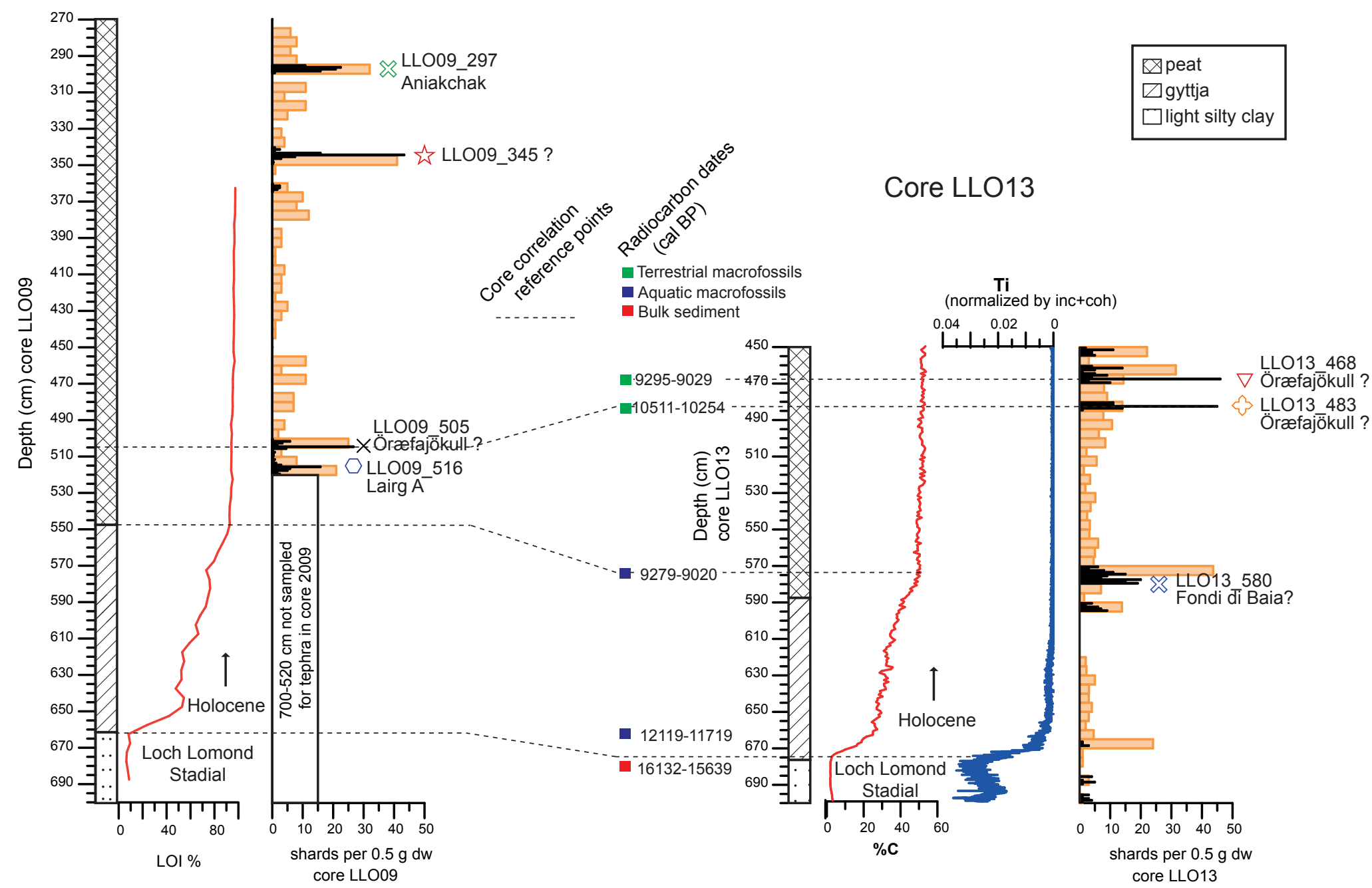


A)
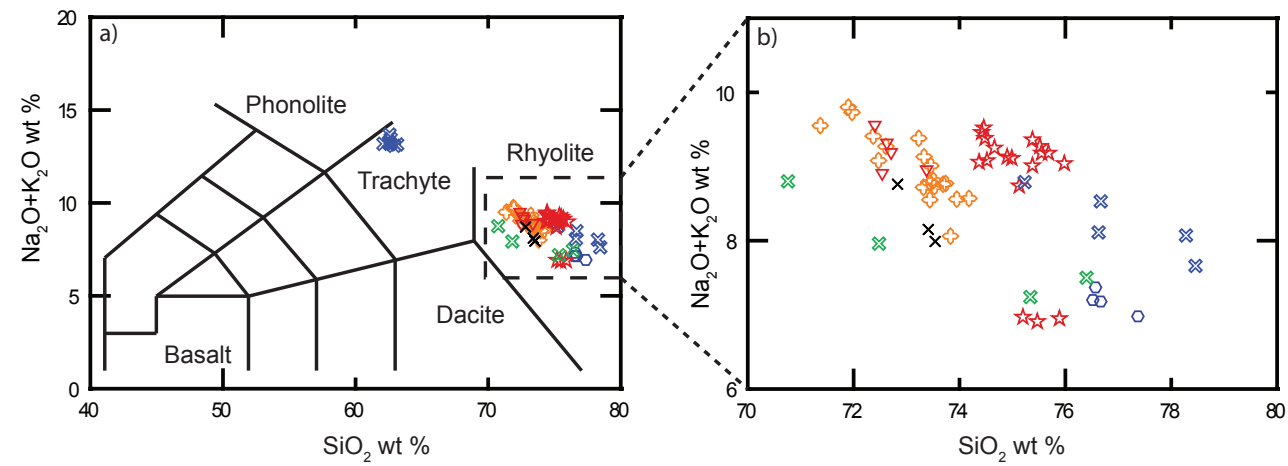

\LLO09_297

论 LLO09_345

$\times$ LLO09_505

$\checkmark$ LLO09_516

$\nabla$ LLO_468

\{ LLO_483

§ LLO_580
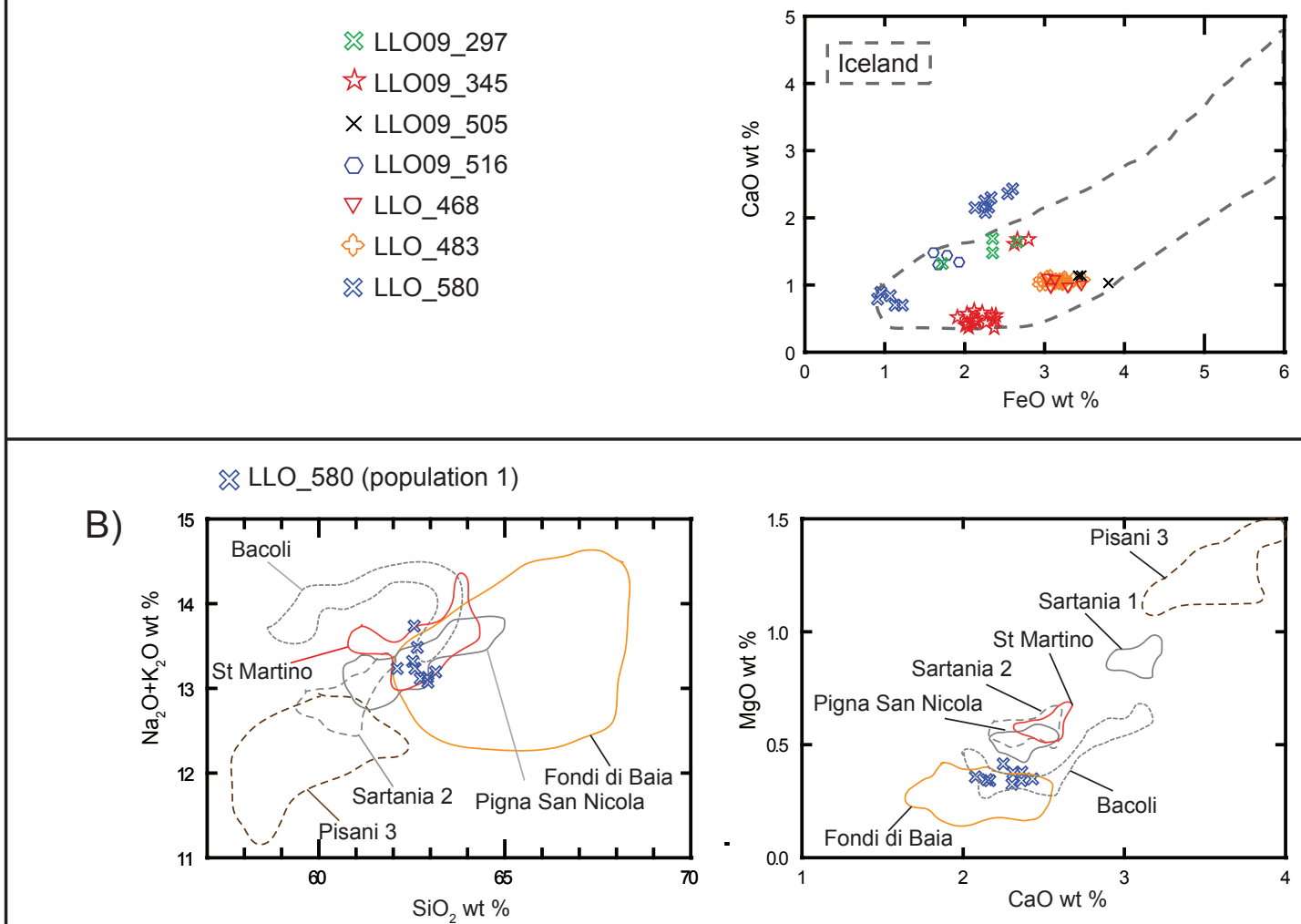

§ LLO_580 (population 2)

C)
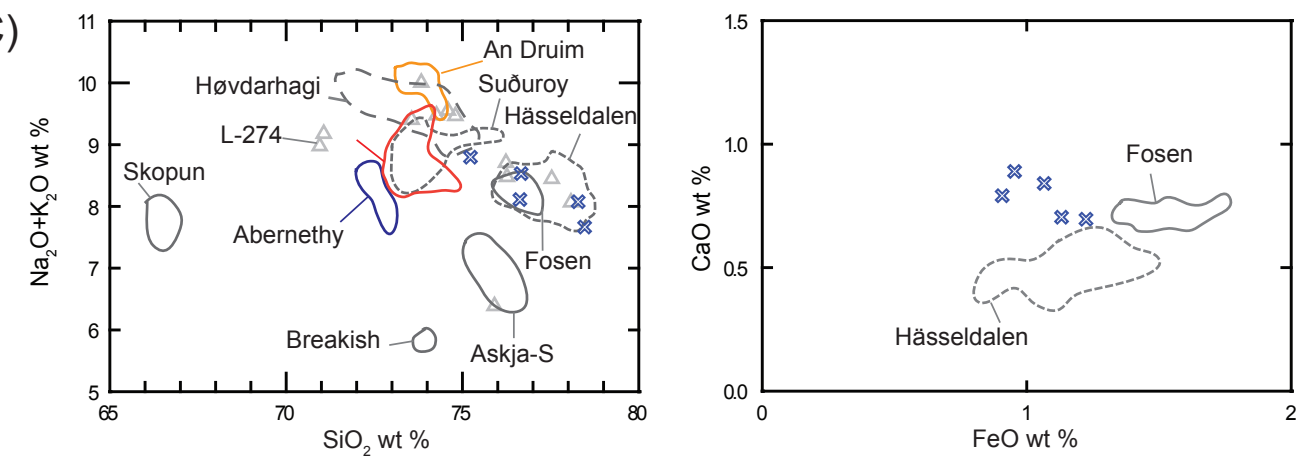

D)

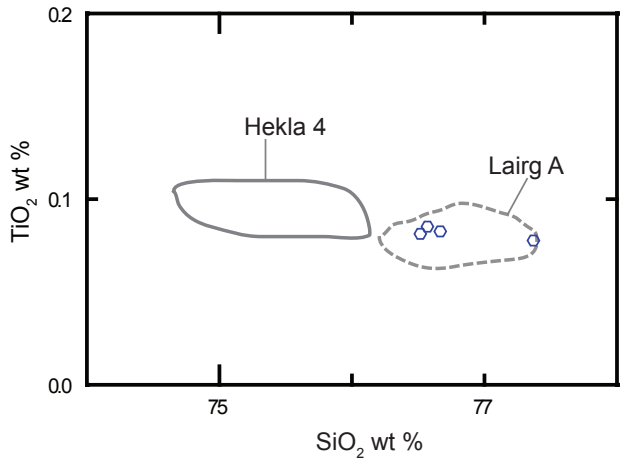

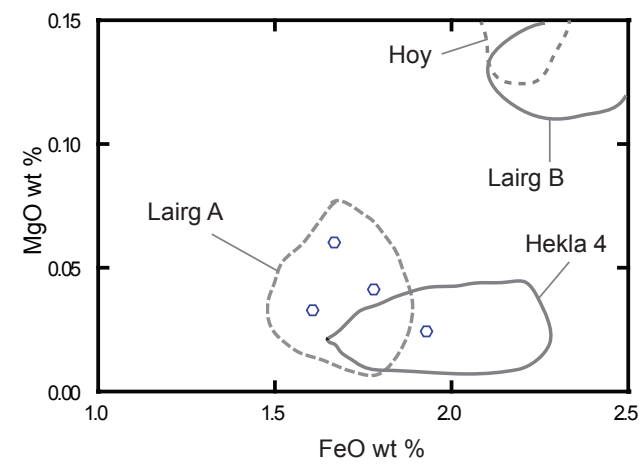




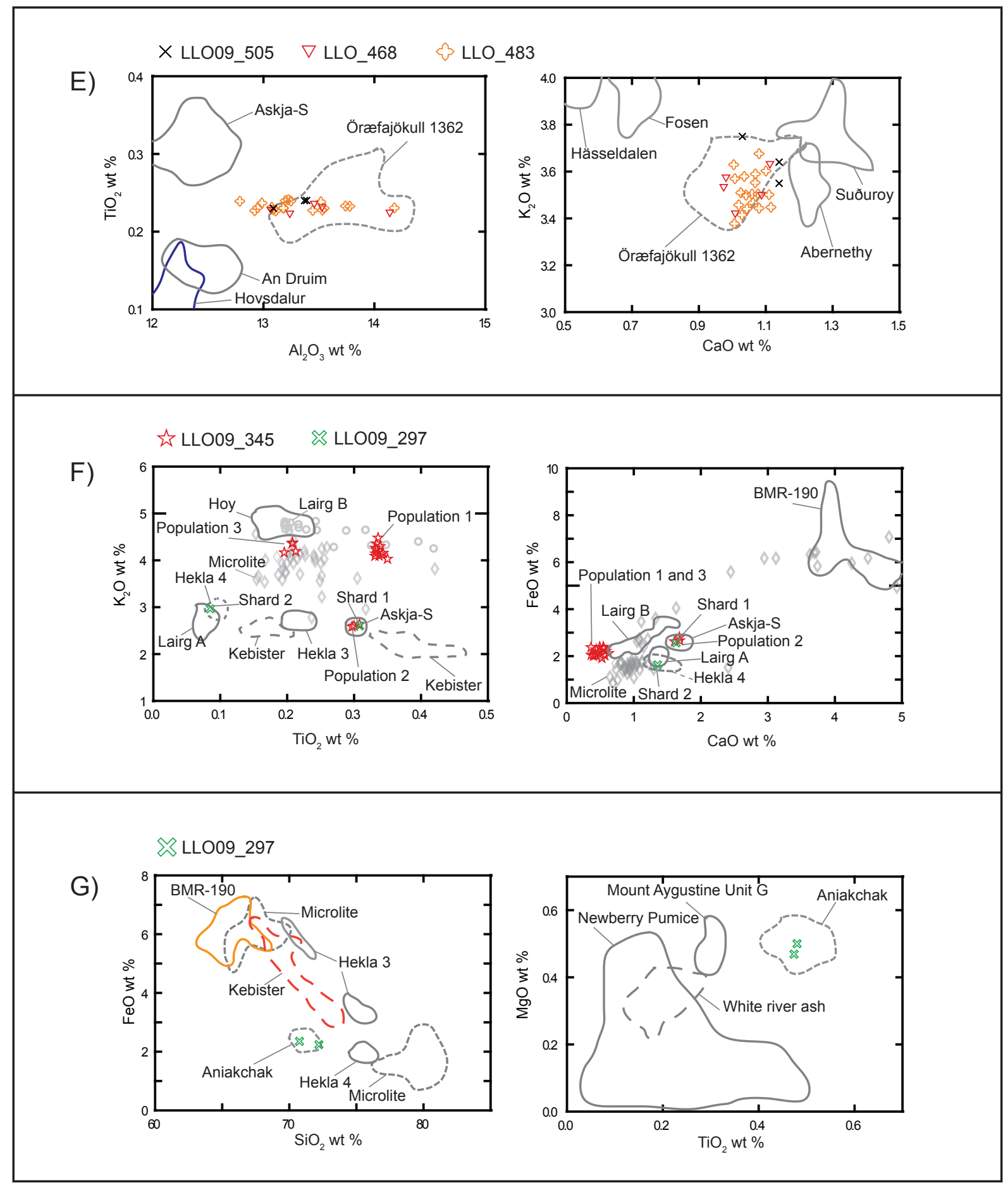


Model B

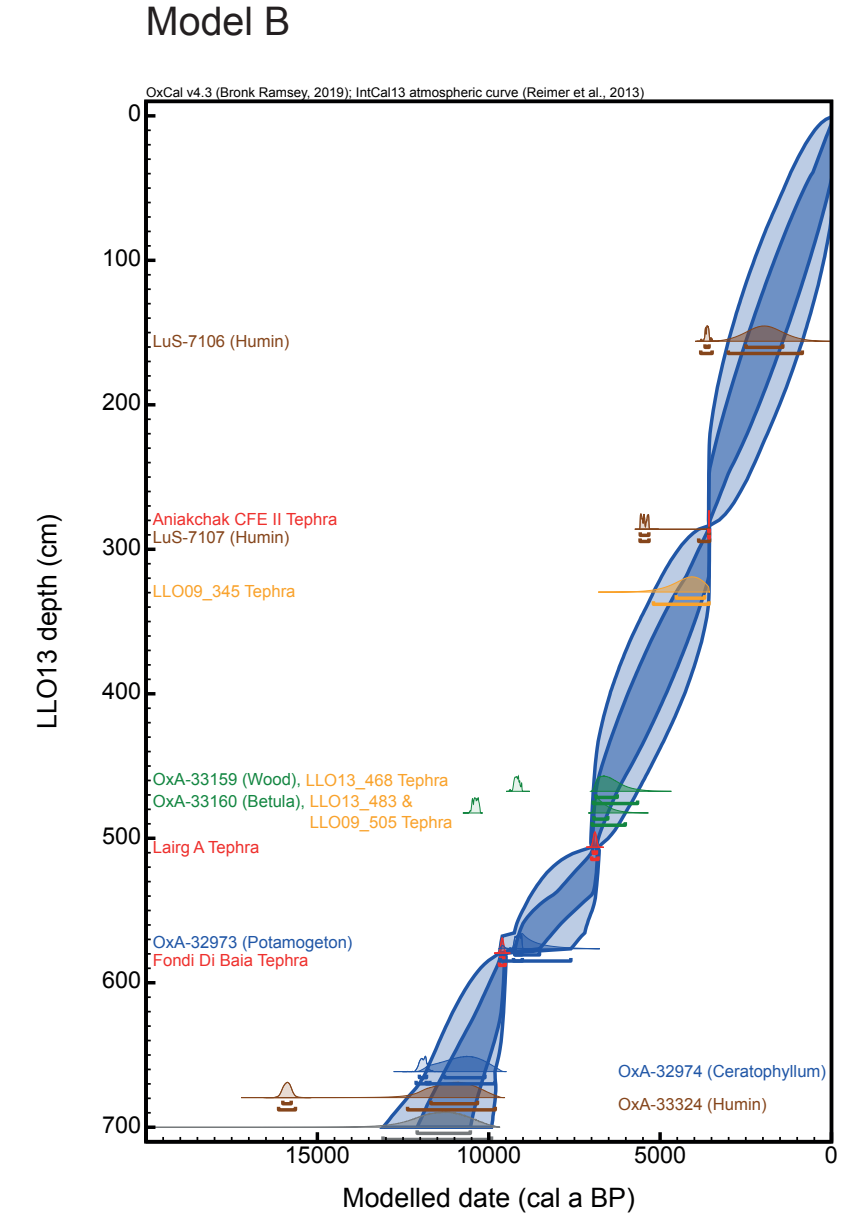

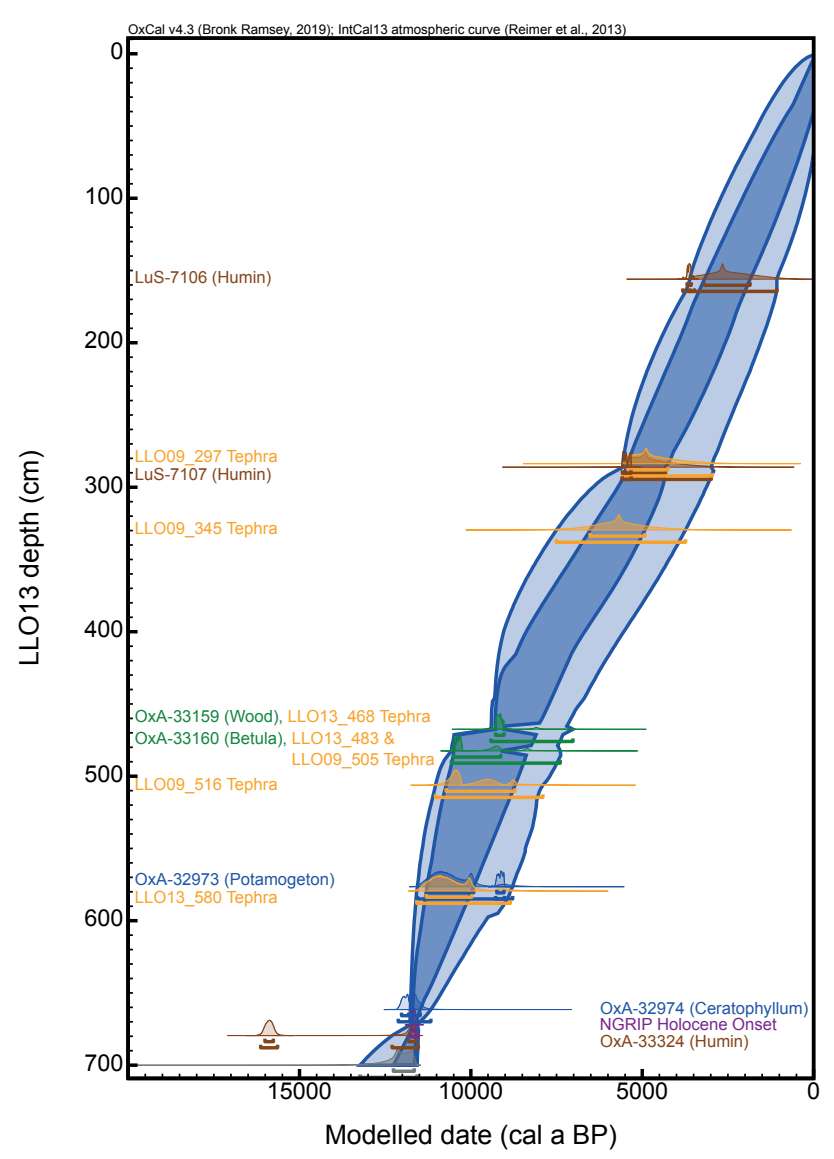


A)

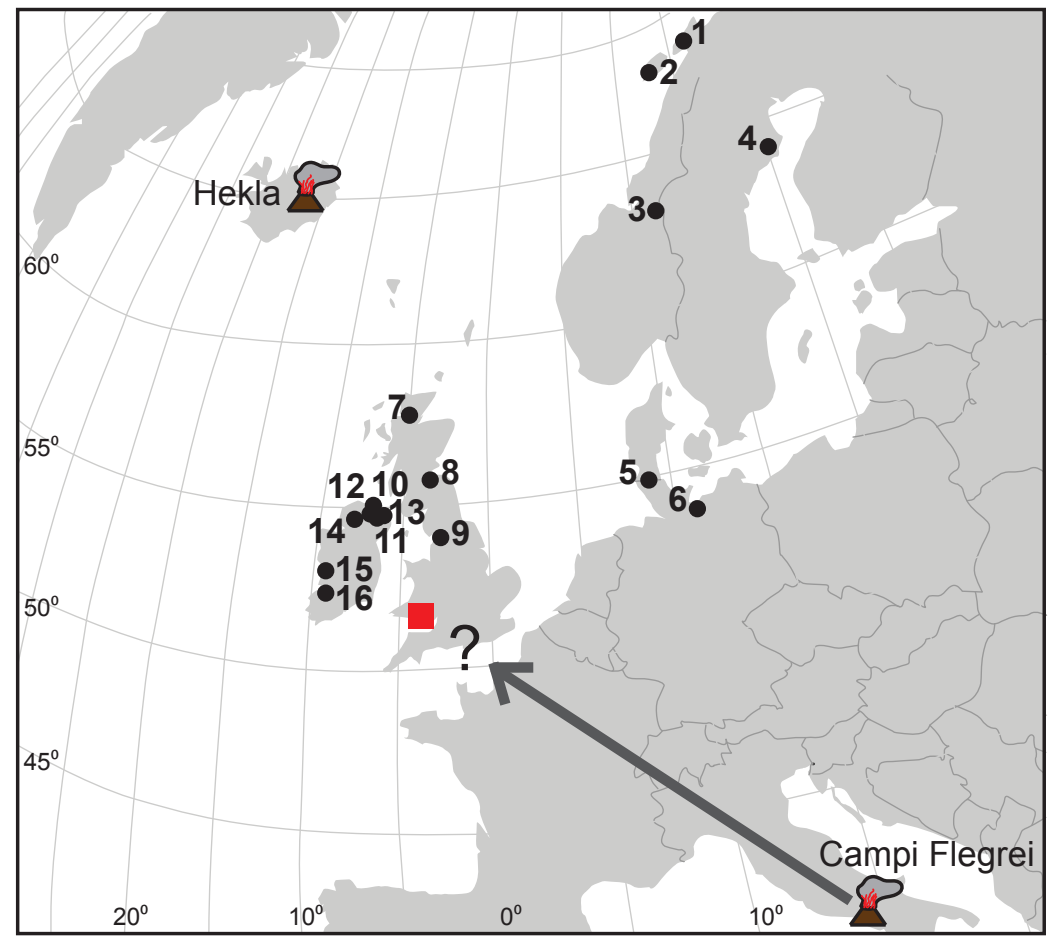

- Lairg A Tephra

A Aniakchak Tephra

Llyn Llech Owain (study site)

B)

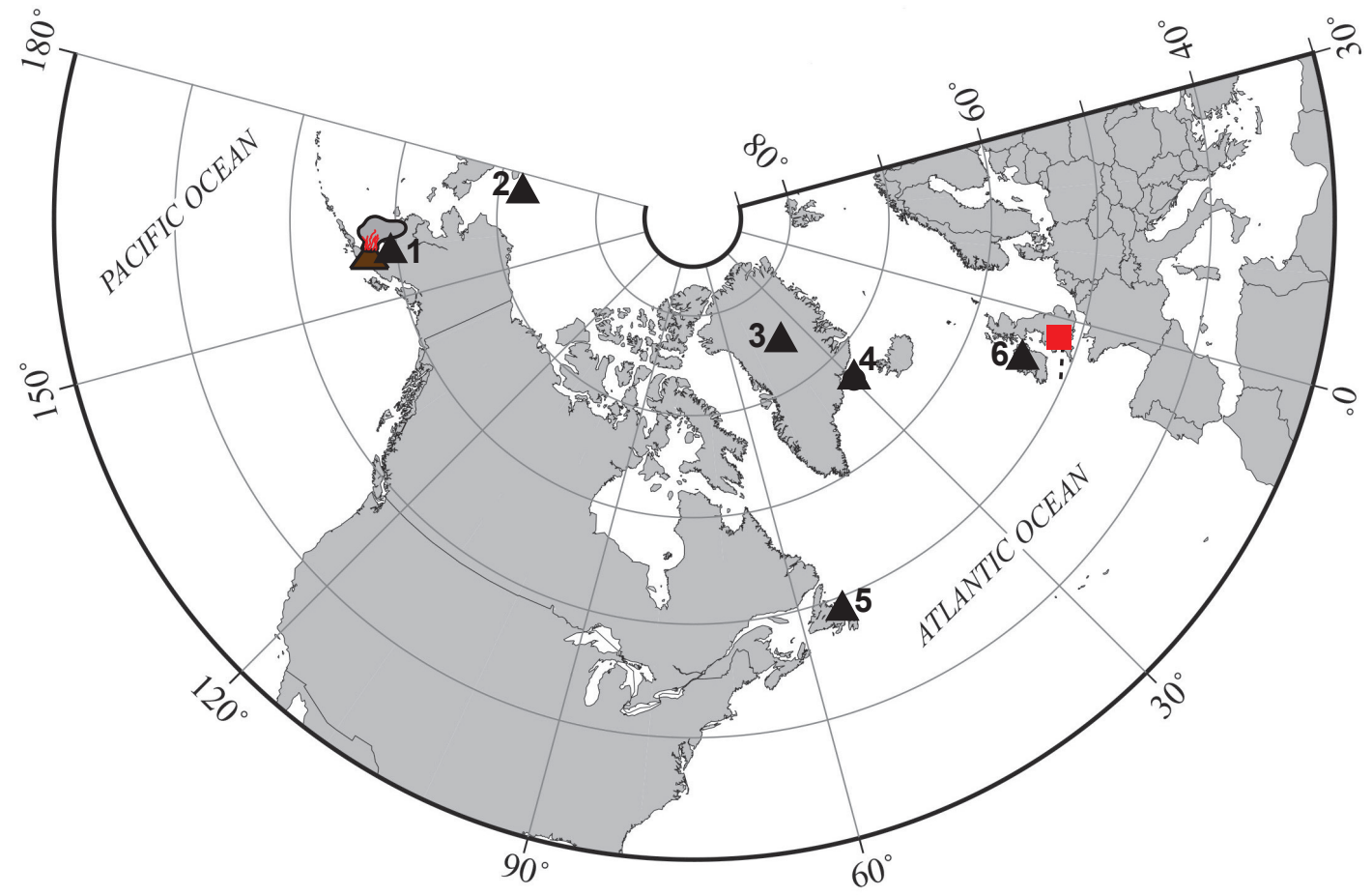




\section{$\begin{array}{lllllllllll}\mathrm{SiO}_{2} & \mathrm{TiO}_{2} & \mathrm{Al}_{2} \mathrm{O}_{3} & \mathrm{FeO} & \mathrm{MnO} & \mathrm{MgO} & \mathrm{CaO} & \mathrm{Na}_{2} \mathrm{O} & \mathrm{K}_{2} \mathrm{O} & \mathrm{P}_{2} \mathrm{O}_{5} & \text { Total }\end{array}$} Observed values: wt \%

\author{
LLO 580 \\ LLO_580 \\ LLO_580 \\ LLO_580 \\ LLO_580 \\ LLO_580 \\ LLO_580 \\ LLO_580 \\ LLO_580 \\ LLO_580 \\ LLO_580 \\ LLO 580 \\ LLO_580 \\ LLO_580
}

LLO_483
LLO_483
LLO_483
LLO_483
LLO_483
LLO_483
LLO_483
LLO_483
LLO_483
LLO_483
LLO_483
LLO_483
LLO_483
LLO_483
LLO_483
LLO_483
LLO_483
LLO_483
LLO_483

LLO_468

LLO_468

LLO_468

LLO_468

LLO_468

LLO09_516

LLO09_516

LLO09_516

LLO09_516 $\begin{array}{lllll}75.21 & 0.11 & 11.29 & 1.09 & 0.04\end{array}$

$\begin{array}{lllllll}73.47 & 0.07 & 12.34 & 0.87 & 0.07 & 0.06 & 0.76\end{array}$

$\begin{array}{llllllll}73.89 & 0.07 & 12.67 & 1.03 & 0.06 & 0.07 & 0.81\end{array}$

$\begin{array}{lllllll}73.77 & 0.11 & 10.82 & 1.15 & 0.05 & 0.07 & 0.66\end{array}$

$\begin{array}{llllll}70.99 & 0.06 & 13.09 & 0.90 & 0.06\end{array}$

$0.10 \quad 0.84$

$\begin{array}{llll}59.60 & 0.35 & 17.93 & 2.49\end{array}$

0.17

$0.33 \quad 2.33$

$\begin{array}{llll}59.89 & 0.35 & 17.86 & 2.16\end{array}$

0.17

$0.40 \quad 2.15$

$\begin{array}{lllll}59.81 & 0.35 & 17.52 & 2.22\end{array}$

0.15

0.312 .20

0.17

0.322 .06

$\begin{array}{llll}59.44 & 0.33 & 17.00 & 2.41\end{array}$

0.16

$\begin{array}{ll}0.32 & 2.24\end{array}$

0.17

$\begin{array}{lll}0.33 & 2.08\end{array}$

0.16

$0.35 \quad 2.03$

$\begin{array}{lllll}61.58 & 0.34 & 17.96 & 2.20\end{array}$

0.15

$0.36 \quad 2.21$

0.15

$\begin{array}{ll}60.08 & 0.32\end{array}$

$\begin{array}{ll}17.88 & 2.11\end{array}$

$0.36 \quad 2.26$

$\begin{array}{lll}3.87 & 3.47 & 0.01\end{array}$

$\begin{array}{lll}3.75 & 4.43 & 0.01\end{array}$

$\begin{array}{lll}3.52 & 4.30 & 0.01\end{array}$

$\begin{array}{lll}3.94 & 3.67 & 0.00\end{array}$

4.23

$\begin{array}{lll}4.07 & 0.02\end{array}$

$\begin{array}{lll}4.26 & 8.44 & 0.05\end{array}$

$\begin{array}{lll}4.26 & 8.50 & 0.05\end{array}$

$\begin{array}{llll}4.39 & 8.48 & 0.03\end{array}$

$\begin{array}{lll}4.08 & 8.42 & 0.04\end{array}$

4.44

4.38

4.30

4.15

4.19

$\begin{array}{ll}8.61 & 0.05\end{array}$

$\begin{array}{lll}8.45 & 0.05\end{array}$

$\begin{array}{lll}8.57 & 0.03\end{array}$

8.370 .06

$\begin{array}{ll}8.37 & 0.07\end{array}$

95.86

95.83

96.43

94.23

94.37

95.96

95.80

95.48

95.21

95.00

96.91

97.53

95.76

95.78

$\begin{array}{llll}72.18 & 0.24 & 13.04 & 3.20\end{array}$

0.10

$0.01 \quad 1.08$

5.04

$\begin{array}{ll}3.55 & 0.00\end{array}$

98.44

$\begin{array}{lllll}72.50 & 0.22 & 12.87 & 2.90\end{array}$

$\begin{array}{lllll}72.30 & 0.24 & 13.02 & 3.30\end{array}$

0.09

0.021 .06

$\begin{array}{lll}5.24 & 3.39 & 0.01\end{array}$

98.31

$\begin{array}{llll}73.18 & 0.23 & 12.77 & 2.90\end{array}$

0.10

0.001 .06

4.793 .62

0.00

98.45

$\begin{array}{llll}71.83 & 0.22 & 12.87 & 3.00\end{array}$

0.10

$0.01 \quad 0.99$

5.12

3.33

0.01

98.65

$\begin{array}{llll}72.79 & 0.23 & 13.36 & 3.10\end{array}$

0.10

0.031 .09

5.16

0.001 .05

4.45

3.37

0.01

97.68

$\begin{array}{llll}71.08 & 0.23 & 12.57 & 3.03\end{array}$

0.10

0.011 .00

5.26

3.46

0.02

98.60

$\begin{array}{lllll}72.67 & 0.22 & 12.89 & 2.96 & 0.09\end{array}$

0.011 .00

5.02

3.40

0.01

96.76

$\begin{array}{lllllll}72.76 & 0.23 & 12.82 & 3.20 & 0.10 & 0.01 & 1.03\end{array}$

5.59

3.47

0.01

98.27

$72.16 \quad 0.24$

$\begin{array}{ll}72.21 & 0.23\end{array}$

$12.96 \quad 2.97$

0.09

0.001 .09

5.21

3.44

0.02

99.22

$\begin{array}{ll}71.07 & 0.22\end{array}$

$\begin{array}{ll}12.96 & 3.17 \\ 12.61 & 2.96\end{array}$

0.09

0.021 .01

5.28

3.36

0.01

98.17

$\begin{array}{lll}71.03 & 0.23\end{array}$

$\begin{array}{lll}13.57 & 3.14\end{array}$

0.10

$0.03 \quad 0.97$

5.01

3.44

0.03

98.32

$\begin{array}{lll}72.96 & 0.23\end{array}$

13.873 .28

0.10

5.29

3.40

0.01

96.45

$\begin{array}{lll}71.66 & 0.24\end{array}$

$13.34 \quad 3.18$

0.09

0.001 .01

5.68

3.53

0.01

98.79

$\begin{array}{lllll}72.38 & 0.24 & 12.64 & 3.15 & 0.08\end{array}$

0.001 .06

5.73

3.55

0.02

$\begin{array}{lll}71.10 & 0.22\end{array}$

$13.30 \quad 3.24$

0.11

0.030 .99

5.68

3.57

0.01

$\begin{array}{lllll}71.42 & 0.23 & 13.34 & 3.41 & 0.09\end{array}$

0.021 .05

6.21

3.44

0.001 .05

5.91

3.43

0.02

98.25

99.24

97.74

$\begin{array}{lllllll}70.61 & 0.22 & 12.87 & 3.36 & 0.10 & 0.02 & 0.98\end{array}$

$\begin{array}{lll}5.74 & 3.33 & 0.00\end{array}$

97.22

$\begin{array}{llll}71.50 & 0.23 & 13.23 & 3.24\end{array}$

0.10

0.02

0.96

5.52

3.52

0.02

98.33

$\begin{array}{llll}71.63 & 0.22 & 13.96 & 3.04\end{array}$

0.11

0.020 .96

$\begin{array}{lll}5.30 & 3.49 & 0.02\end{array}$

98.74

$\begin{array}{lllll}72.03 & 0.22 & 12.83 & 3.07\end{array}$

0.11

0.02

1.07

5.36

$\begin{array}{ll}3.44 & 0.01\end{array}$

98.15

$\begin{array}{lllll}71.53 & 0.23 & 13.37 & 2.99\end{array}$

0.10

$0.02 \quad 1.10$

98.79 $\begin{array}{ll}73.41 & 0.08 \\ 73.13 & 0.08\end{array}$

$\begin{array}{llllll}73.13 & 0.08 & 12.29 & 1.70 & 0.08\end{array}$

$\begin{array}{llllll}74.22 & 0.07 & 11.97 & 1.60 & 0.06\end{array}$

$\begin{array}{lllll}74.55 & 0.08 & 12.37 & 1.88 & 0.06\end{array}$
$0.03 \quad 1.42$

0.041 .37

$0.06 \quad 1.25$

$0.02 \quad 1.30$ $\begin{array}{lll}4.14 & 2.93 & 0.01\end{array}$

$\begin{array}{lll}4.17 & 2.72 & 0.00\end{array}$

$\begin{array}{lll}3.98 & 2.72 & 0.01\end{array}$

$\begin{array}{lll}4.23 & 2.75 & 0.01\end{array}$
95.88

95.58

95.92

97.24 
$\begin{array}{llllllllllll}\text { LLO09_505 } & 73.09 & 0.23 & 13.13 & 3.82 & 0.14 & 0.10 & 1.03 & 5.03 & 3.76 & 0.03 & 100.35 \\ \text { LLO09_505 } & 74.26 & 0.24 & 13.50 & 3.50 & 0.13 & 0.11 & 1.15 & 4.48 & 3.58 & 0.02 & 100.97 \\ \text { LLO09_505 } & 73.86 & 0.24 & 13.48 & 3.44 & 0.14 & 0.08 & 1.15 & 4.53 & 3.67 & 0.02 & 100.62\end{array}$

$\begin{array}{llllllllllll}\text { LLO09_345 } & 69.88 & 0.31 & 12.35 & 2.09 & 0.11 & 0.13 & 0.55 & 4.55 & 3.97 & 0.02 & 93.96\end{array}$

LLO09_345 $\quad \begin{array}{llllllllllll}72.33 & 0.34 & 12.16 & 2.29 & 0.11 & 0.13 & 0.47 & 4.53 & 3.88 & 0.02 & 96.27\end{array}$

LLO09_345 $\quad \begin{array}{llllllllllll}71.41 & 0.32 & 12.48 & 2.03 & 0.11 & 0.15 & 0.60 & 4.58 & 4.12 & 0.02 & 95.83\end{array}$

LLO09_345 $\quad \begin{array}{lllllllllll}71.52 & 0.33 & 12.37 & 1.83 & 0.12 & 0.10 & 0.50 & 4.75 & 3.97 & 0.01 & 95.49\end{array}$

$\begin{array}{lllllllllllll}\text { LLO09_345 } & 73.01 & 0.19 & 11.68 & 2.29 & 0.07 & 0.02 & 0.35 & 4.84 & 4.02 & 0.00 & 96.47\end{array}$

LLO09_345 $\quad \begin{array}{llllllllllll}71.74 & 0.32 & 12.14 & 2.30 & 0.13 & 0.12 & 0.53 & 5.09 & 3.94 & 0.01 & 96.33\end{array}$

LLO09_345 $\quad \begin{array}{llllllllllll}70.93 & 0.32 & 12.01 & 2.23 & 0.13 & 0.14 & 0.53 & 5.07 & 3.95 & 0.01 & 95.31\end{array}$

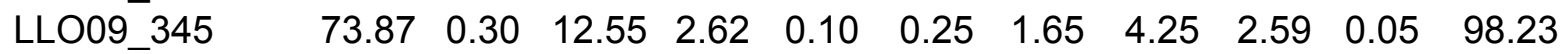

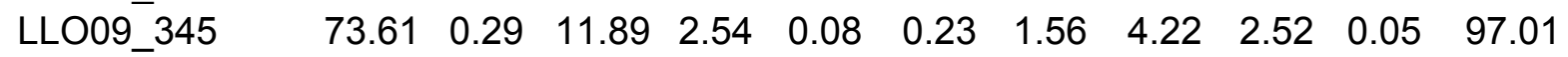

$\begin{array}{llllllllllll}\text { LLO09_345 } & 73.36 & 0.29 & 12.10 & 2.72 & 0.09 & 0.25 & 1.63 & 4.20 & 2.51 & 0.05 & 97.21\end{array}$

LLO09_345 $\quad \begin{array}{llllllllllll}71.43 & 0.32 & 12.48 & 1.94 & 0.11 & 0.11 & 0.41 & 4.69 & 4.17 & 0.02 & 95.67\end{array}$

LLO09_345 $\quad \begin{array}{llllllllllll}72.32 & 0.20 & 11.70 & 2.18 & 0.09 & 0.04 & 0.42 & 4.61 & 4.17 & 0.00 & 95.73\end{array}$

LLO09_345 $\quad \begin{array}{llllllllllll}72.45 & 0.32 & 11.84 & 1.97 & 0.10 & 0.07 & 0.35 & 4.89 & 4.10 & 0.02 & 96.11\end{array}$

$\begin{array}{llllllllllll}\text { LLO09_345 } & 73.09 & 0.20 & 11.85 & 2.08 & 0.09 & 0.04 & 0.45 & 4.73 & 4.23 & 0.01 & 96.77\end{array}$

$\begin{array}{llllllllllll}\text { LLO09_345 } & 70.28 & 0.31 & 11.59 & 1.98 & 0.11 & 0.10 & 0.44 & 4.58 & 3.82 & 0.02 & 93.23\end{array}$

$\begin{array}{lllllllllllll}\text { LLO09_345 } & 72.62 & 0.20 & 11.59 & 2.01 & 0.09 & 0.02 & 0.41 & 4.64 & 4.01 & 0.00 & 95.58\end{array}$

LLO09_345 $\quad \begin{array}{llllllllllll} & 72.11 & 0.33 & 12.22 & 1.95 & 0.12 & 0.12 & 0.55 & 4.79 & 3.97 & 0.01 & 96.15\end{array}$

$\begin{array}{lllllllllllll}\text { LLO09_345 } & 71.58 & 0.32 & 12.59 & 1.93 & 0.11 & 0.06 & 0.38 & 4.84 & 4.31 & 0.03 & 96.14\end{array}$

$\begin{array}{llllllllllll}\text { LLO09_297 } & 74.25 & 0.31 & 12.29 & 2.62 & 0.08 & 0.22 & 1.62 & 4.57 & 2.56 & 0.03 & 98.55\end{array}$

LLO09_297 $\quad \begin{array}{llllllllllll}73.93 & 0.07 & 12.47 & 1.66 & 0.07 & 0.04 & 1.27 & 4.37 & 2.88 & 0.01 & 96.77\end{array}$

LLO09_297 $\quad \begin{array}{llllllllllll}70.74 & 0.48 & 15.19 & 2.35 & 0.15 & 0.50 & 1.68 & 5.95 & 2.85 & 0.08 & 99.97\end{array}$

LLO09_297 $\quad \begin{array}{llllllllllll} & 71.02 & 0.47 & 14.50 & 2.20 & 0.14 & 0.46 & 1.60 & 5.07 & 2.82 & 0.09 & 98.36\end{array}$ 


\section{\begin{tabular}{cc}
\hline Standard file & $\begin{array}{c}\text { Beam size } \\
\mu \mathrm{m}\end{array}$
\end{tabular}$\quad$ Date}

b $\quad 5 \quad 3 / 1 / 201612: 52$

b $\quad 5 \quad 3 / 1 / 201612: 59$

b $\quad 5 \quad 3 / 1 / 201613: 29$

c $\quad 3 \quad 3 / 2 / 201612: 49$

c $\quad 3 \quad 3 / 2 / 201612: 57$

b $\quad 5 \quad 3 / 1 / 201613: 07$

b $\quad 5 \quad 3 / 1 / 201613: 13$

c $\quad 3 \quad 3 / 2 / 201613: 13$

C $\quad 3 \quad 3 / 2 / 201613: 29$

c $\quad 3 \quad 3 / 2 / 201613: 36$

C $\quad 3 \quad 3 / 2 / 201613: 44$

$\begin{array}{lll}c & 3 & 3 / 2 / 201613: 51\end{array}$

e $\quad 5 \quad 10 / 10 / 201610: 37$

e $\quad 5 \quad 10 / 10 / 201610: 43$

$\begin{array}{lll}C & 5 & 3 / 2 / 201619: 01\end{array}$

C $\quad 5 \quad 3 / 2 / 201619: 08$

C $\quad 5 \quad 3 / 2 / 201619: 15$

C $\quad 5 \quad 3 / 2 / 201619: 20$

C $\quad 5 \quad 3 / 2 / 201619: 26$

$\begin{array}{lll}\text { C } & 5 & 3 / 2 / 201619: 37\end{array}$

C $\quad 5 \quad 3 / 2 / 201619: 42$

C $\quad 5 \quad 3 / 2 / 201619: 55$

C $\quad 5 \quad 3 / 2 / 201620: 02$

C $\quad 5 \quad 3 / 2 / 201620: 09$

C $\quad 5 \quad 3 / 2 / 201620: 15$

c $\quad 5 \quad 3 / 2 / 201620: 23$

a $\quad 3 \quad 12 / 1 / 201413: 48$

$\begin{array}{lll}\text { a } & 3 & 12 / 1 / 201413: 57\end{array}$

$\begin{array}{lll}\text { a } & 3 & 12 / 1 / 201414: 07\end{array}$

a $\quad 3 \quad 12 / 1 / 201414: 25$

a $\quad 3 \quad 12 / 1 / 201414: 33$

a $\quad 3 \quad 12 / 1 / 201414: 49$

a $\quad 3 \quad 12 / 1 / 201415: 06$

a

a

$12 / 1 / 201415: 23$

$12 / 1 / 201415: 31$

$12 / 1 / 201415: 41$

$12 / 1 / 201415: 50$

$12 / 1 / 201416: 34$

$\begin{array}{lll}\text { b } & 5 & 3 / 1 / 201615: 39 \\ \text { b } & 5 & 3 / 1 / 201615: 45 \\ \text { b } & 5 & 3 / 1 / 201615: 51 \\ \text { b } & 5 & 3 / 1 / 201615: 57\end{array}$




$\begin{array}{lll}\text { c } & 5 & 3 / 2 / 201618: 16 \\ \text { c } & 5 & 3 / 2 / 201618: 22 \\ \text { c } & 5 & 3 / 2 / 201618: 28 \\ & & \\ \text { c } & 3 & 3 / 2 / 201614: 08 \\ \text { c } & 3 & 3 / 2 / 201614: 16 \\ \text { c } & 3 & 3 / 2 / 201614: 25 \\ \text { c } & 3 & 3 / 2 / 201614: 33 \\ \text { c } & 3 & 3 / 2 / 201614: 41 \\ \text { c } & 3 & 3 / 2 / 201614: 50 \\ \text { c } & 3 & 3 / 2 / 201614: 57 \\ \text { c } & 3 & 3 / 2 / 201615: 15 \\ \text { c } & 3 & 3 / 2 / 201615: 22 \\ \text { c } & 3 & 3 / 2 / 201615: 29 \\ \text { d } & 5 & 3 / 4 / 20163: 42 \\ \text { d } & 5 & 3 / 4 / 20163: 48 \\ \text { d } & 5 & 3 / 4 / 20163: 54 \\ \text { d } & 5 & 3 / 4 / 20164: 00 \\ \text { d } & 5 & 3 / 4 / 20164: 06 \\ \text { d } & 5 & 3 / 4 / 20164: 12 \\ \text { d } & 5 & 3 / 4 / 20164: 18 \\ \text { d } & 5 & 3 / 4 / 20164: 24 \\ & & \\ \text { c } & 3 & 3 / 2 / 201615: 36 \\ \text { c } & 3 & 3 / 201615: 53 \\ \text { c } & 5 & 10 / 10 / 201610: 45 \\ \text { e } & 3 & \end{array}$




\begin{tabular}{|c|c|c|c|c|c|c|c|c|c|c|c|}
\hline \multicolumn{11}{|c|}{ Preferred values: (Sparks (1990) } & Total \\
\hline Lipari min & 73.43 & 0.07 & 12.52 & 1.5 & 0.07 & & 0.7 & 3.96 & 5.08 & & \\
\hline Lipari max & 74.63 & 0.09 & 12.92 & 1.8 & 0.09 & & 0.74 & 4.16 & 5.28 & & \\
\hline \multicolumn{12}{|c|}{ Preferred values: Wilson (1997) } \\
\hline BCR2g min & 53.3 & 2.21 & 13.3 & 12.21 & & 3.54 & 7.01 & 3.05 & 1.74 & 0.33 & \\
\hline BCR2g max & 54.9 & 2.31 & 13.7 & 12.61 & & 3.64 & 7.23 & 3.27 & 1.84 & 0.37 & \\
\hline
\end{tabular}

$\begin{array}{cccccccccccc}\text { BCR2g } & 54.00 & 2.26 & 13.52 & 12.05 & 0.19 & 3.58 & 6.90 & 3.58 & 1.85 & 0.36 & 98.30 \\ \text { BCR2g } & 53.21 & 2.27 & 14.15 & 12.64 & 0.20 & 3.69 & 6.89 & 3.39 & 1.78 & 0.37 & 98.57 \\ \text { BCR2g } & 54.44 & 2.28 & 14.65 & 12.17 & 0.19 & 3.74 & 7.08 & 3.28 & 1.77 & 0.37 & 99.97 \\ \text { BCR2g } & 54.45 & 2.28 & 14.24 & 12.80 & 0.19 & 3.67 & 7.11 & 3.45 & 1.83 & 0.37 & 100.39 \\ \text { BCR2g } & 54.12 & 2.26 & 13.85 & 12.15 & 0.20 & 3.67 & 7.04 & 3.21 & 1.81 & 0.35 & 98.65 \\ \text { Lipari } & 74.09 & 0.07 & 13.61 & 1.37 & 0.07 & 0.05 & 0.77 & 4.75 & 5.18 & 0.00 & 99.97 \\ \text { Lipari } & 74.14 & 0.09 & 13.74 & 1.44 & 0.07 & 0.06 & 0.80 & 4.52 & 5.09 & -0.01 & 99.93 \\ \text { Lipari } & 74.58 & 0.07 & 13.83 & 1.50 & 0.06 & 0.06 & 0.81 & 4.51 & 4.85 & 0.01 & 100.29 \\ \text { Lipari } & 74.10 & 0.08 & 13.08 & 1.73 & 0.06 & 0.05 & 0.68 & 4.96 & 5.03 & 0.00 & 99.76 \\ \text { Lipari } & 73.48 & 0.08 & 13.77 & 1.44 & 0.06 & 0.03 & 0.73 & 4.45 & 5.14 & 0.01 & 99.20 \\ \text { Lipari } & 73.29 & 0.07 & 11.56 & 1.63 & 0.07 & 0.08 & 0.67 & 4.17 & 5.10 & 0.01 & 96.64 \\ \text { Lipari } & 73.18 & 0.08 & 13.26 & 1.53 & 0.07 & 0.05 & 0.77 & 4.53 & 5.16 & 0.01 & 98.64 \\ \text { Lipari } & 74.13 & 0.08 & 14.45 & 1.48 & 0.06 & 0.07 & 0.75 & 4.57 & 5.15 & 0.01 & 100.74 \\ \text { Lipari } & 73.49 & 0.07 & 13.70 & 1.61 & 0.06 & 0.03 & 0.77 & 4.48 & 5.21 & 0.01 & 99.43 \\ \text { Lipari } & 73.85 & 0.07 & 13.55 & 1.40 & 0.08 & 0.06 & 0.69 & 4.28 & 5.05 & 0.01 & 99.05 \\ \text { Lipari } & 73.71 & 0.07 & 13.33 & 1.47 & 0.07 & 0.04 & 0.77 & 4.02 & 5.26 & 0.00 & 98.75 \\ \text { Lipari } & 73.32 & 0.09 & 13.52 & 1.71 & 0.06 & 0.03 & 0.68 & 4.31 & 5.24 & 0.01 & 98.97 \\ \text { BCR2g } & 54.10 & 2.27 & 13.19 & 12.25 & 0.20 & 3.65 & 7.13 & 3.39 & 1.81 & 0.30 & 98.30 \\ \text { BCR2g } & 54.28 & 2.27 & 13.47 & 12.77 & 0.20 & 3.57 & 7.17 & 3.33 & 1.82 & 0.31 & 99.18 \\ \text { BCR2g } & 54.09 & 2.26 & 13.29 & 12.42 & 0.19 & 3.61 & 7.12 & 3.41 & 1.91 & 0.33 & 98.62 \\ \text { BCR2g } & 54.08 & 2.27 & 13.32 & 12.30 & 0.20 & 3.70 & 7.12 & 3.39 & 1.78 & 0.33 & 98.49 \\ \text { BCR2g } & 54.39 & 2.26 & 13.78 & 12.86 & 0.19 & 3.62 & 7.13 & 3.22 & 1.83 & 0.30 & 99.60\end{array}$

$\begin{array}{cccccccccccc}\text { Lipari } & 74.38 & 0.06 & 12.79 & 1.63 & 0.07 & 0.03 & 0.80 & 4.07 & 5.08 & 0.00 & 98.93 \\ \text { Lipari } & 74.50 & 0.07 & 12.90 & 1.65 & 0.08 & 0.09 & 0.76 & 4.24 & 5.20 & 0.00 & 99.50 \\ \text { Lipari } & 74.21 & 0.08 & 13.10 & 1.56 & 0.08 & 0.02 & 0.73 & 4.23 & 5.15 & 0.01 & 99.17 \\ \text { Lipari } & 74.82 & 0.08 & 13.11 & 1.64 & 0.07 & 0.06 & 0.66 & 4.27 & 5.10 & 0.00 & 99.80 \\ \text { BCR2g } & 53.11 & 2.26 & 13.27 & 12.83 & 0.20 & 3.71 & 7.44 & 2.66 & 1.77 & 0.31 & 97.56 \\ \text { BCR2g } & 53.79 & 2.27 & 13.54 & 12.23 & 0.21 & 3.55 & 7.21 & 3.25 & 1.76 & 0.33 & 98.14 \\ \text { BCR2g } & 52.97 & 2.26 & 13.09 & 12.40 & 0.21 & 3.61 & 7.00 & 3.15 & 1.90 & 0.32 & 96.90 \\ \text { BCR2g } & 54.20 & 2.28 & 13.44 & 11.98 & 0.20 & 3.59 & 7.03 & 3.00 & 1.83 & 0.33 & 97.88 \\ \text { BCR2g } & 54.03 & 2.27 & 13.22 & 12.85 & 0.19 & 3.65 & 7.11 & 3.49 & 1.85 & 0.36 & 99.03 \\ \text { BCR2g } & 54.59 & 2.28 & 13.39 & 12.28 & 0.20 & 3.47 & 7.12 & 3.26 & 1.88 & 0.36 & 98.84 \\ \text { BCR2g } & 54.09 & 2.29 & 13.16 & 12.44 & 0.19 & 3.61 & 7.06 & 3.35 & 1.86 & 0.35 & 98.41 \\ \text { BCR2g } & 54.01 & 2.29 & 13.36 & 11.88 & 0.21 & 3.42 & 7.00 & 3.14 & 1.70 & 0.34 & 97.35 \\ \text { BCR2g } & 54.19 & 2.29 & 13.24 & 12.04 & 0.19 & 3.64 & 7.19 & 3.32 & 1.85 & 0.35 & 98.31 \\ \text { BCR2g } & 55.19 & 2.27 & 12.82 & 12.20 & 0.20 & 3.51 & 6.92 & 3.27 & 1.87 & 0.34 & 98.59 \\ \text { Lipari } & 73.38 & 0.07 & 13.18 & 1.52 & 0.07 & 0.02 & 0.79 & 4.16 & 5.12 & 0.01 & 98.33 \\ \text { Lipari } & 73.11 & 0.07 & 12.94 & 1.57 & 0.08 & 0.05 & 0.72 & 3.96 & 5.14 & 0.01 & 97.63 \\ \text { Lipari } & 73.10 & 0.08 & 13.16 & 1.61 & 0.07 & 0.04 & 0.72 & 3.94 & 5.05 & 0.01 & 97.77\end{array}$




$\begin{array}{cccccccccccc}\text { Lipari } & 73.42 & 0.07 & 12.62 & 1.70 & 0.07 & 0.07 & 0.79 & 4.20 & 5.37 & 0.02 & 98.31 \\ \text { Lipari } & 74.48 & 0.08 & 13.45 & 1.57 & 0.07 & 0.05 & 0.76 & 4.16 & 5.12 & 0.02 & 99.75 \\ \text { Lipari } & 73.77 & 0.08 & 12.61 & 1.70 & 0.07 & 0.01 & 0.74 & 4.15 & 5.14 & 0.00 & 98.25 \\ \text { Lipari } & 73.86 & 0.08 & 13.05 & 1.69 & 0.06 & 0.03 & 0.74 & 4.11 & 5.18 & 0.00 & 98.79 \\ \text { Lipari } & 73.89 & 0.08 & 13.00 & 1.37 & 0.07 & 0.05 & 0.71 & 4.07 & 5.15 & 0.01 & 98.41 \\ \text { Lipari } & 74.29 & 0.08 & 12.84 & 1.59 & 0.07 & 0.06 & 0.76 & 4.14 & 5.15 & 0.01 & 98.97 \\ \text { Lipari } & 73.79 & 0.08 & 13.11 & 1.55 & 0.07 & 0.05 & 0.83 & 4.08 & 5.09 & 0.01 & 98.65 \\ \text { Lipari } & 75.16 & 0.07 & 12.98 & 1.61 & 0.07 & 0.05 & 0.74 & 4.23 & 5.11 & 0.00 & 100.01 \\ \text { BCR2g } & 54.07 & 2.30 & 13.57 & 11.57 & 0.20 & 3.52 & 7.10 & 3.46 & 1.73 & 0.33 & 97.86 \\ \text { BCR2g } & 53.86 & 2.29 & 13.32 & 11.85 & 0.19 & 3.41 & 7.05 & 3.25 & 1.70 & 0.36 & 97.27 \\ \text { BCR2g } & 53.42 & 2.30 & 13.29 & 11.80 & 0.20 & 3.69 & 7.12 & 3.08 & 1.74 & 0.34 & 96.96 \\ \text { Lipari } & 73.73 & 0.08 & 13.13 & 1.41 & 0.06 & 0.02 & 0.77 & 4.19 & 5.20 & 0.01 & 98.59 \\ \text { Lipari } & 74.23 & 0.08 & 13.03 & 1.55 & 0.07 & 0.04 & 0.71 & 4.24 & 5.17 & 0.01 & 99.13 \\ \text { Lipari } & 73.94 & 0.07 & 12.96 & 1.55 & 0.07 & 0.05 & 0.80 & 4.00 & 5.12 & 0.01 & 98.58 \\ \text { Lipari } & 74.19 & 0.08 & 12.85 & 1.41 & 0.05 & 0.04 & 0.75 & 4.03 & 5.13 & 0.00 & 98.54 \\ \text { Lipari } & 73.97 & 0.08 & 12.99 & 1.68 & 0.08 & 0.08 & 0.75 & 4.06 & 5.17 & 0.00 & 98.86 \\ \text { Lipari } & 74.09 & 0.08 & 12.97 & 1.57 & 0.07 & 0.05 & 0.79 & 4.14 & 5.15 & 0.00 & 98.91 \\ \text { Lipari } & 74.35 & 0.08 & 12.59 & 1.60 & 0.07 & 0.02 & 0.76 & 4.16 & 5.20 & 0.01 & 98.84 \\ \text { BCR2g } & 53.92 & 2.26 & 13.15 & 12.04 & 0.20 & 3.70 & 7.04 & 3.07 & 1.74 & 0.30 & 97.42 \\ \text { BCR2g } & 54.31 & 2.29 & 13.58 & 11.89 & 0.19 & 3.71 & 7.15 & 3.24 & 1.81 & 0.32 & 98.48 \\ \text { BCR2g } & 54.31 & 2.29 & 13.56 & 12.01 & 0.21 & 3.70 & 7.02 & 3.42 & 1.88 & 0.32 & 98.72 \\ \text { BCR2g } & 54.66 & 2.30 & 13.23 & 12.29 & 0.20 & 3.53 & 7.30 & 3.24 & 1.83 & 0.33 & 98.91 \\ \text { BCR2g } & 54.23 & 2.26 & 13.92 & 12.47 & 0.19 & 3.61 & 7.15 & 3.70 & 2.00 & 0.32 & 99.85 \\ \text { BCR2g } & 53.74 & 2.29 & 13.51 & 12.46 & 0.21 & 3.57 & 7.11 & 3.48 & 1.93 & 0.30 & 98.62 \\ \text { BCR2g } & 55.95 & 2.29 & 13.58 & 13.14 & 0.20 & 3.67 & 7.18 & 1.09 & 1.86 & 0.32 & 99.27\end{array}$

$\begin{array}{cccccccccccc}\text { BCR2g } & 55.16 & 2.26 & 13.19 & 12.41 & 0.20 & 3.57 & 7.14 & 3.08 & 1.82 & 0.36 & 99.21 \\ \text { BCR2g } & 54.39 & 2.26 & 13.34 & 11.99 & 0.20 & 3.64 & 7.09 & 3.37 & 1.76 & 0.37 & 98.40 \\ \text { BCR2g } & 54.12 & 2.26 & 13.08 & 12.43 & 0.21 & 3.71 & 7.07 & 3.34 & 1.75 & 0.36 & 98.33 \\ \text { Lipari } & 74.09 & 0.08 & 12.85 & 1.42 & 0.07 & 0.02 & 0.72 & 4.00 & 5.36 & 0.01 & 98.62 \\ \text { Lipari } & 75.08 & 0.08 & 13.10 & 1.62 & 0.08 & 0.05 & 0.78 & 4.28 & 5.27 & 0.00 & 100.34 \\ \text { Lipari } & 74.15 & 0.08 & 12.14 & 1.69 & 0.06 & 0.01 & 0.74 & 4.13 & 5.30 & 0.00 & 98.29 \\ \text { Lipari } & 73.52 & 0.08 & 12.37 & 1.63 & 0.07 & 0.05 & 0.73 & 4.22 & 5.35 & 0.00 & 98.03 \\ \text { Lipari } & 74.23 & 0.07 & 12.47 & 1.50 & 0.06 & 0.06 & 0.71 & 4.24 & 5.12 & 0.02 & 98.47 \\ \text { BCR2g } & 54.47 & 2.28 & 14.15 & 12.48 & 0.20 & 3.65 & 7.06 & 3.28 & 1.74 & 0.35 & 99.66 \\ \text { BCR2g } & 54.19 & 2.26 & 13.72 & 12.84 & 0.20 & 3.70 & 7.42 & 3.20 & 1.73 & 0.36 & 99.62 \\ \text { BCR2g } & 53.88 & 2.27 & 14.21 & 12.49 & 0.20 & 3.65 & 7.34 & 3.11 & 1.71 & 0.36 & 99.24 \\ \text { Lipari } & 73.90 & 0.08 & 12.85 & 1.51 & 0.07 & 0.02 & 0.74 & 4.03 & 5.09 & 0.00 & 98.28 \\ \text { Lipari } & 74.28 & 0.08 & 13.07 & 1.65 & 0.08 & 0.04 & 0.76 & 4.03 & 5.25 & 0.01 & 99.24 \\ \text { Lipari } & 74.22 & 0.08 & 13.50 & 1.58 & 0.06 & 0.04 & 0.72 & 4.31 & 5.19 & 0.01 & 99.71 \\ \text { Lipari } & 73.94 & 0.08 & 12.93 & 1.58 & 0.07 & 0.03 & 0.79 & 3.77 & 5.19 & 0.00 & 98.38 \\ \text { Lipari } & 74.13 & 0.08 & 13.15 & 1.46 & 0.05 & 0.04 & 0.79 & 3.93 & 5.34 & 0.00 & 98.98 \\ \text { Lipari } & 73.94 & 0.08 & 12.69 & 1.80 & 0.07 & 0.05 & 0.74 & 3.89 & 5.31 & 0.00 & 98.57 \\ \text { BCR2g } & 53.93 & 2.24 & 13.37 & 12.33 & 0.19 & 3.60 & 7.10 & 3.12 & 1.82 & 0.35 & 98.06 \\ \text { BCR2g } & 54.53 & 2.28 & 13.61 & 12.70 & 0.20 & 3.55 & 6.98 & 3.26 & 1.86 & 0.36 & 99.34 \\ \text { BCR2g } & 53.77 & 2.28 & 13.32 & 12.62 & 0.19 & 3.65 & 7.20 & 3.38 & 1.72 & 0.35 & 98.49 \\ \text { BCR2g } & 55.55 & 2.28 & 13.41 & 12.29 & 0.20 & 3.61 & 7.32 & 3.35 & 1.76 & 0.34 & 100.11 \\ \text { BCR2g } & 55.18 & 2.26 & 13.40 & 12.08 & 0.18 & 3.64 & 7.10 & 3.19 & 1.75 & 0.35 & 99.14 \\ \text { Lipari } & 73.84 & 0.08 & 12.81 & 1.40 & 0.06 & 0.02 & 0.70 & 4.25 & 5.12 & 0.01 & 98.29 \\ \text { Lipari } & 74.47 & 0.08 & 13.19 & 1.64 & 0.06 & 0.06 & 0.71 & 4.20 & 5.27 & 0.01 & 99.69 \\ \text { Lipari } & 74.29 & 0.08 & 13.31 & 1.62 & 0.07 & 0.05 & 0.76 & 4.22 & 5.21 & 0.02 & 99.64 \\ \text { Lipari } & 74.19 & 0.08 & 13.24 & 1.43 & 0.06 & 0.05 & 0.76 & 4.01 & 5.18 & 0.01 & 99.01\end{array}$




$\begin{array}{cccccccccccc}\text { Lipari } & 73.60 & 0.07 & 12.84 & 1.60 & 0.08 & 0.04 & 0.78 & 4.14 & 5.22 & -0.01 & 98.37 \\ \text { Lipari } & 73.72 & 0.07 & 13.01 & 1.43 & 0.07 & 0.03 & 0.82 & 4.12 & 5.09 & 0.00 & 98.36 \\ \text { Lipari } & 73.59 & 0.07 & 12.84 & 1.49 & 0.07 & 0.04 & 0.78 & 4.29 & 5.40 & 0.01 & 98.57 \\ \text { BCR2g } & 54.93 & 2.27 & 13.50 & 12.11 & 0.19 & 3.58 & 7.19 & 3.32 & 1.87 & 0.35 & 99.32 \\ \text { BCR2g } & 54.78 & 2.29 & 13.75 & 12.37 & 0.19 & 3.58 & 7.24 & 3.35 & 1.82 & 0.36 & 99.73 \\ \text { BCR2g } & 55.22 & 2.27 & 13.87 & 12.89 & 0.22 & 3.73 & 7.09 & 3.29 & 1.82 & 0.35 & 100.75 \\ \text { Lipari } & 75.05 & 0.07 & 12.70 & 1.55 & 0.06 & 0.05 & 0.79 & 4.15 & 5.10 & 0.00 & 99.53 \\ \text { Lipari } & 73.69 & 0.08 & 12.89 & 1.46 & 0.07 & 0.06 & 0.75 & 3.93 & 5.19 & 0.01 & 98.12 \\ \text { Lipari } & 74.95 & 0.07 & 13.12 & 1.45 & 0.07 & 0.05 & 0.75 & 3.94 & 5.28 & 0.00 & 99.69 \\ \text { Lipari } & 74.81 & 0.08 & 13.19 & 1.44 & 0.07 & 0.02 & 0.69 & 4.10 & 5.45 & 0.00 & 99.85 \\ \text { Lipari } & 74.49 & 0.08 & 13.29 & 1.82 & 0.06 & 0.05 & 0.73 & 4.34 & 5.15 & 0.01 & 100.03 \\ \text { Lipari } & 74.48 & 0.08 & 13.11 & 1.64 & 0.07 & 0.01 & 0.68 & 4.11 & 5.16 & 0.01 & 99.35 \\ \text { Lipari } & 74.85 & 0.08 & 13.28 & 1.40 & 0.07 & 0.05 & 0.80 & 4.12 & 5.17 & 0.01 & 99.83 \\ \text { Lipari } & 74.65 & 0.08 & 13.24 & 1.59 & 0.07 & 0.05 & 0.71 & 4.27 & 5.21 & 0.00 & 99.87 \\ \text { BCR2g } & 54.71 & 2.29 & 13.62 & 12.74 & 0.21 & 3.56 & 7.14 & 3.20 & 1.74 & 0.34 & 99.56 \\ \text { BCR2g } & 54.43 & 2.29 & 13.32 & 12.84 & 0.20 & 3.66 & 7.04 & 3.25 & 1.84 & 0.36 & 99.22 \\ \text { BCR2g } & 54.84 & 2.27 & 13.31 & 12.83 & 0.21 & 3.69 & 7.02 & 3.20 & 1.74 & 0.36 & 99.45 \\ \text { BCR2g } & 55.68 & 2.29 & 13.61 & 12.72 & 0.21 & 3.65 & 7.10 & 3.40 & 1.74 & 0.36 & 100.76 \\ \text { BCR2g } & 54.94 & 2.31 & 13.35 & 12.26 & 0.21 & 3.54 & 7.07 & 3.16 & 1.91 & 0.34 & 99.10 \\ \text { BCR2g } & 54.78 & 2.28 & 13.57 & 12.51 & 0.19 & 3.52 & 7.18 & 3.27 & 1.82 & 0.38 & 99.51 \\ \text { BCR2g } & 55.09 & 2.28 & 13.58 & 12.57 & 0.22 & 3.57 & 7.11 & 3.22 & 1.93 & 0.36 & 99.93 \\ \text { BCR2g } & 54.09 & 2.29 & 13.63 & 12.73 & 0.20 & 3.51 & 7.29 & 3.29 & 1.79 & 0.35 & 99.17\end{array}$

\begin{tabular}{|c|c|c|c|c|c|c|c|c|c|c|c|}
\hline Lipari & 4.02 & 0.08 & 12.84 & 1.61 & 0.06 & 0.04 & 0.74 & 4.05 & 5.09 & 0.01 & \\
\hline Lipari & 74.93 & 0.07 & 13.11 & 1.51 & 0.06 & 0.01 & 0.74 & 4.25 & 5.28 & 0.01 & \\
\hline Lipari & 74.59 & 0.08 & 13.05 & 1.47 & 0.08 & 0.02 & 0.75 & 4.14 & 5.20 & 0.00 & 9.39 \\
\hline BCR2g & 54.41 & 2.29 & 13.39 & 12.73 & 0.21 & 3.57 & 7.06 & 3.34 & 1.80 & 0.37 & 9.17 \\
\hline $3 \mathrm{CR} 2 \mathrm{~g}$ & 54.94 & 2.28 & 13.34 & 12.67 & 0.21 & 3.67 & 7.17 & 3.40 & 1.79 & 0.37 & 9.84 \\
\hline CR2g & 54.01 & 2.28 & 13.34 & 12.09 & 0.21 & 3.72 & 7.12 & 3.36 & .82 & 0.36 & 8.32 \\
\hline Lipari & 74.50 & 0.07 & 12.97 & 1.71 & 0.06 & 0.03 & 0.81 & 4.19 & 5.12 & 0.01 & 9.48 \\
\hline Lipari & 74.33 & 0.07 & 12.84 & 1.63 & 0.08 & 0.02 & 0.76 & 4.24 & 5.15 & 0.01 & 9.11 \\
\hline Lipari & 74.31 & 0.08 & 13.05 & 1.63 & 0.07 & 0.01 & 0.69 & 4.20 & 5.19 & 0.01 & 9.24 \\
\hline Lipari & 73.73 & 0.08 & 13.25 & 1.60 & 0.06 & 0.06 & 0.69 & 4.12 & 5.31 & 0.01 & 8.91 \\
\hline BCR2g & 54.71 & 2.28 & 13.39 & 12.47 & 0.19 & 3.71 & 7.07 & 3.25 & 1.77 & 0.36 & 99.21 \\
\hline BCR2g & 53.78 & 2.36 & 13.72 & 12.50 & 0.20 & 3.66 & 7.12 & 3.34 & 1.80 & 0.35 & 98.84 \\
\hline CR2g & 53.45 & 2.28 & 13.47 & 12.54 & 0.21 & 3.62 & 7.10 & 3.19 & 1.83 & 0.38 & 8.0 \\
\hline BCR2g & 53.81 & 2.27 & 13.69 & 12.72 & 0.20 & 3.57 & 7.08 & 3.21 & 1.76 & 0.37 & 98.67 \\
\hline Lipari & 74.63 & 0.08 & 13.25 & 1.51 & 0.07 & 0.05 & 0.81 & 4.08 & 5.10 & 0.02 & 99.60 \\
\hline Lipari & 74.02 & 0.08 & 13.21 & 1.66 & 0.06 & 0.02 & 0.79 & 4.24 & 5.38 & 0.01 & 99.48 \\
\hline Lipari & 74.79 & 0.08 & 12.96 & 1.47 & 0.07 & 0.03 & 0.78 & 4.16 & 5.10 & 0.02 & 9.45 \\
\hline Lipari & 74.67 & 0.08 & 13.24 & 1.65 & 0.07 & 0.03 & 0.73 & 4.20 & 5.15 & 0.01 & 99.83 \\
\hline Lipari & 74.08 & 0.07 & 13.15 & 1.59 & 0.07 & 0.03 & 0.73 & 4.05 & 5.06 & 0.01 & 98.85 \\
\hline Lipari & 73.37 & 0.08 & 12.71 & 1.49 & 0.07 & 0.03 & 0.76 & 4.00 & 5.07 & 0.02 & 97.60 \\
\hline BCR2g & 54.03 & 2.28 & 13.68 & 12.40 & 0.20 & 3.44 & 6.90 & 3.32 & 1.76 & 0.35 & 98.37 \\
\hline BCR2g & 54.54 & 2.29 & 13.64 & 12.50 & 0.20 & 3.55 & 7.14 & 3.37 & 1.85 & 0.34 & 99.42 \\
\hline BCR2g & 54.41 & 2.28 & 13.74 & 12.33 & 0.21 & 3.53 & 7.33 & 3.17 & 1.71 & 0.34 & 99.05 \\
\hline Lipari & 74.57 & 0.08 & 13.19 & 1.48 & 0.07 & 0.03 & 0.78 & 4.23 & 5.34 & 0.01 & 99.77 \\
\hline Lipari & 73.95 & 0.08 & 12.98 & 1.66 & 0.07 & 0.06 & 0.80 & 4.21 & 5.16 & 0.01 & 98.97 \\
\hline Lipari & 73.73 & 0.07 & 12.99 & 1.76 & 0.08 & 0.05 & 0.76 & 4.17 & 4.97 & 0.01 & 98.59 \\
\hline & 73.45 & 0.08 & 12.89 & 2.02 & 0.08 & 0.05 & 0.76 & 4.16 & 5.25 & 0.01 & 98.75 \\
\hline & 73.37 & 0.07 & 12.70 & 1.54 & 0.07 & 0.02 & 0.77 & 4.25 & 4.99 & 0.01 & 97.79 \\
\hline תחת & 54.29 & 2.30 & 13.39 & 11.94 & 0.21 & 3.57 & 7.13 & 3.89 & 1.80 & 0.33 & 98.85 \\
\hline
\end{tabular}




$\begin{array}{cccccccccccc}\text { BCR2g } & 53.89 & 2.25 & 13.51 & 12.28 & 0.19 & 3.53 & 6.95 & 3.54 & 1.76 & 0.33 & 98.25 \\ \text { BCR2g } & 54.20 & 2.28 & 13.75 & 12.58 & 0.20 & 3.58 & 7.29 & 3.33 & 1.79 & 0.34 & 99.34 \\ \text { BCR2g } & 54.49 & 2.28 & 13.40 & 12.44 & 0.20 & 3.44 & 6.94 & 3.20 & 1.83 & 0.36 & 98.60 \\ \text { BCR2g } & 54.52 & 2.30 & 13.88 & 12.16 & 0.20 & 3.58 & 7.09 & 3.23 & 1.80 & 0.35 & 99.11 \\ \text { Lipari } & 74.52 & 0.07 & 13.06 & 1.57 & 0.07 & 0.04 & 0.72 & 4.20 & 5.12 & 0.00 & 99.37 \\ \text { Lipari } & 74.25 & 0.08 & 12.92 & 1.68 & 0.07 & 0.05 & 0.68 & 4.14 & 5.06 & 0.01 & 98.94 \\ \text { Lipari } & 73.81 & 0.08 & 13.09 & 1.53 & 0.06 & 0.03 & 0.74 & 4.06 & 5.19 & 0.01 & 98.60 \\ \text { Lipari } & 74.42 & 0.07 & 13.20 & 1.69 & 0.06 & 0.06 & 0.76 & 3.98 & 5.23 & 0.00 & 99.48 \\ \text { Lipari } & 75.35 & 0.09 & 13.35 & 1.60 & 0.05 & 0.04 & 0.76 & 4.13 & 5.16 & 0.00 & 100.53 \\ \text { Lipari } & 73.97 & 0.08 & 13.35 & 1.55 & 0.06 & 0.04 & 0.76 & 3.97 & 5.18 & 0.00 & 98.97 \\ \text { Lipari } & 73.95 & 0.07 & 12.87 & 1.53 & 0.06 & 0.06 & 0.73 & 4.00 & 5.22 & 0.00 & 98.48 \\ \text { Lipari } & 74.01 & 0.08 & 13.01 & 1.70 & 0.07 & 0.04 & 0.78 & 4.13 & 5.25 & 0.01 & 99.08 \\ \text { BCR2g } & 53.77 & 2.28 & 13.73 & 12.07 & 0.20 & 3.65 & 7.19 & 3.27 & 1.81 & 0.35 & 98.32 \\ \text { BCR2g } & 53.71 & 2.25 & 13.58 & 12.81 & 0.20 & 3.61 & 7.07 & 3.25 & 1.84 & 0.33 & 98.64 \\ \text { BCR2g } & 54.72 & 2.28 & 13.35 & 12.11 & 0.21 & 3.58 & 7.15 & 3.30 & 1.86 & 0.33 & 98.90 \\ \text { BCR2g } & 54.01 & 2.26 & 13.71 & 12.47 & 0.21 & 3.57 & 7.05 & 3.34 & 1.81 & 0.32 & 98.74 \\ \text { BCR2g } & 53.94 & 2.26 & 13.76 & 12.30 & 0.20 & 3.52 & 7.29 & 4.10 & 1.77 & 0.34 & 99.48 \\ \text { BCR2g } & 53.66 & 2.27 & 13.80 & 12.48 & 0.19 & 3.54 & 6.95 & 3.40 & 1.77 & 0.33 & 98.40 \\ \text { BCR2g } & 54.40 & 2.27 & 13.60 & 12.33 & 0.20 & 3.67 & 7.14 & 3.26 & 1.79 & 0.35 & 99.01 \\ \text { BCR2g } & 53.46 & 2.26 & 13.84 & 12.39 & 0.20 & 3.63 & 7.26 & 3.31 & 1.84 & 0.33 & 98.52\end{array}$

$\begin{array}{cccccccccccc}\text { BCR2g } & 54.61 & 2.27 & 13.39 & 12.34 & 0.21 & 3.64 & 7.16 & 2.70 & 1.68 & 0.34 & 98.34 \\ \text { BCR2g } & 54.84 & 2.27 & 13.05 & 11.98 & 0.20 & 3.64 & 7.14 & 3.14 & 1.88 & 0.35 & 98.50 \\ \text { BCR2g } & 54.30 & 2.25 & 13.01 & 12.90 & 0.20 & 3.62 & 7.24 & 3.04 & 1.82 & 0.37 & 98.75 \\ \text { Lipari } & 74.87 & 0.07 & 12.38 & 1.55 & 0.06 & 0.04 & 0.74 & 4.09 & 5.16 & 0.01 & 98.97 \\ \text { Lipari } & 75.35 & 0.07 & 12.67 & 1.38 & 0.07 & 0.08 & 0.75 & 4.03 & 5.09 & 0.01 & 99.49 \\ \text { Lipari } & 75.16 & 0.08 & 13.02 & 1.68 & 0.07 & 0.05 & 0.70 & 4.17 & 5.16 & 0.01 & 100.10 \\ \text { BCR2g } & 55.01 & 2.24 & 13.60 & 12.67 & 0.20 & 3.68 & 7.11 & 3.18 & 1.86 & 0.34 & 99.90 \\ \text { BCR2g } & 54.60 & 2.25 & 13.15 & 12.64 & 0.19 & 3.57 & 7.25 & 3.25 & 1.81 & 0.34 & 99.07 \\ \text { Lipari } & 73.54 & 0.08 & 12.34 & 1.58 & 0.06 & 0.06 & 0.70 & 4.15 & 5.25 & 0.01 & 97.76 \\ \text { Lipari } & 74.14 & 0.07 & 12.35 & 1.48 & 0.07 & 0.04 & 0.79 & 4.25 & 4.98 & 0.01 & 98.18 \\ \text { Lipari } & 74.31 & 0.08 & 12.63 & 1.45 & 0.06 & 0.01 & 0.77 & 4.18 & 5.16 & 0.00 & 98.64 \\ \text { Lipari } & 74.00 & 0.08 & 12.55 & 1.45 & 0.07 & 0.04 & 0.78 & 4.05 & 4.90 & 0.01 & 97.91 \\ \text { Lipari } & 73.86 & 0.07 & 12.60 & 1.34 & 0.06 & 0.03 & 0.73 & 4.20 & 5.17 & -0.01 & 98.05 \\ \text { BCR2g } & 54.40 & 2.23 & 13.09 & 12.62 & 0.20 & 3.59 & 7.08 & 3.21 & 1.81 & 0.36 & 98.58 \\ \text { BCR2g } & 54.52 & 2.26 & 12.91 & 12.39 & 0.21 & 3.71 & 7.11 & 3.30 & 1.77 & 0.36 & 98.54 \\ \text { BCR2g } & 53.73 & 2.25 & 12.71 & 12.57 & 0.19 & 3.71 & 7.12 & 3.27 & 1.81 & 0.33 & 97.69 \\ \text { BCR2g } & 54.77 & 2.26 & 13.01 & 12.63 & 0.19 & 3.73 & 7.23 & 2.96 & 1.75 & 0.38 & 98.92 \\ \text { BCR2g } & 54.33 & 2.23 & 12.87 & 12.45 & 0.20 & 3.69 & 7.10 & 3.34 & 1.82 & 0.36 & 98.38\end{array}$




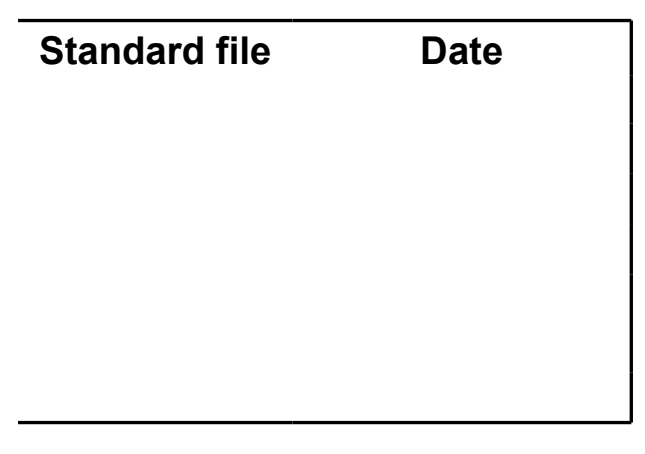

$12 / 1 / 201410: 52$

$12 / 1 / 201410: 59$

$12 / 1 / 201411: 05$

$12 / 1 / 201412: 24$

$12 / 1 / 201412: 30$

$12 / 1 / 201411: 12$

$12 / 1 / 201411: 18$

$12 / 1 / 201411: 48$

$12 / 1 / 201411: 54$

$12 / 1 / 2014$ 12:01

$12 / 1 / 201412: 09$

$12 / 1 / 201412: 15$

$12 / 1 / 201418: 09$

$12 / 1 / 201418: 15$

$12 / 1 / 201418: 22$

$12 / 1 / 201418: 28$

$12 / 1 / 201418: 35$

$12 / 1 / 201418: 43$

$12 / 1 / 201418: 48$

$12 / 1 / 201418: 53$

$12 / 1 / 201419: 02$

12/1/2014 19:08

$3 / 1 / 20167: 45$

$3 / 1 / 20167: 50$

$3 / 1 / 20167: 56$

$3 / 1 / 20168: 01$

$3 / 1 / 20168: 06$

$3 / 1 / 20168: 11$

$3 / 1 / 20168: 17$

$3 / 1 / 20168: 22$

3/1/2016 9:01

3/1/2016 9:07

$3 / 1 / 20169: 12$

$3 / 1 / 2016$ 13:59

$3 / 1 / 201614: 05$

$3 / 1 / 201614: 10$

$3 / 1 / 201614: 15$

$3 / 1 / 201614: 21$

$3 / 1 / 201614: 26$ 
$3 / 1 / 201614: 31$

$3 / 1 / 201614: 39$

$3 / 1 / 201614: 44$

$3 / 1 / 201614: 51$

$3 / 1 / 201614: 57$

$3 / 1 / 201619: 32$

$3 / 1 / 2016$ 19:37

$3 / 1 / 201619: 43$

$3 / 1 / 201619: 48$

$3 / 1 / 201619: 53$

$3 / 1 / 201619: 58$

$3 / 1 / 201623: 23$

$3 / 1 / 201623: 28$

$3 / 1 / 201623: 33$

$3 / 1 / 201623: 39$

$3 / 1 / 201623: 44$

$3 / 1 / 201623: 49$

$3 / 1 / 201623: 54$

$3 / 2 / 20160: 00$

$3 / 2 / 2016$ 0:05

$3 / 2 / 2016$ 0:10

$3 / 2 / 20160: 16$

$3 / 2 / 20160: 21$

$3 / 2 / 20160: 26$

$3 / 2 / 20160: 31$

$3 / 2 / 20169: 59$

$3 / 2 / 201610: 06$

$3 / 2 / 201610: 12$

$3 / 2 / 201610: 19$

$3 / 2 / 201610: 25$

$3 / 2 / 201610: 32$

$3 / 2 / 201610: 47$

$3 / 2 / 201610: 40$

$3 / 2 / 201617: 12$

$3 / 2 / 201617: 18$

$3 / 2 / 201617: 25$

$3 / 2 / 201617: 31$

$3 / 2 / 201617: 37$

$3 / 2 / 201617: 44$

$3 / 2 / 201617: 50$

$3 / 2 / 201617: 57$

$3 / 2 / 201618: 03$

$3 / 2 / 201616: 16$

$3 / 2 / 201616: 21$

$3 / 2 / 201616: 51$

$3 / 2 / 201616: 56$

$3 / 2 / 201617: 01$

$3 / 2 / 201616: 27$

$3 / 2 / 201616: 32$

$3 / 2 / 201616: 38$

$3 / 2 / 201616: 43$ 


\begin{tabular}{|c|c|}
\hline & $3 / 2 / 201620: 44$ \\
\hline & $3 / 2 / 201620: 49$ \\
\hline & $3 / 2 / 201620: 54$ \\
\hline & $3 / 2 / 201621: 04$ \\
\hline & $3 / 2 / 201621: 09$ \\
\hline & $3 / 2 / 201621: 14$ \\
\hline & $3 / 3 / 20160: 37$ \\
\hline & 3/3/2016 0:42 \\
\hline & 3/3/2016 0:47 \\
\hline & $3 / 3 / 20160: 53$ \\
\hline & $3 / 3 / 20160: 58$ \\
\hline & $3 / 3 / 20161: 03$ \\
\hline & $3 / 3 / 20161: 08$ \\
\hline & $3 / 3 / 20161: 14$ \\
\hline & $3 / 3 / 20161: 19$ \\
\hline & $3 / 3 / 20161: 24$ \\
\hline & $3 / 3 / 20161: 29$ \\
\hline & $3 / 3 / 20161: 35$ \\
\hline & $3 / 3 / 20161: 40$ \\
\hline & $3 / 3 / 20161: 45$ \\
\hline & $3 / 3 / 20161: 50$ \\
\hline & $161: 56$ \\
\hline
\end{tabular}

d

$3 / 3 / 20168: 34$

$3 / 3 / 20168: 40$

$3 / 3 / 20168: 45$

$3 / 3 / 20168: 50$

$3 / 3 / 20168: 55$

$3 / 3 / 20169: 01$

$3 / 3 / 201614: 34$

$3 / 3 / 201614: 40$

$3 / 3 / 201614: 45$

$3 / 3 / 201614: 50$

$3 / 3 / 201614: 55$

$3 / 3 / 201615: 01$

$3 / 3 / 201615: 06$

$3 / 3 / 201615: 11$

$3 / 3 / 201617: 38$

$3 / 3 / 201617: 43$

$3 / 3 / 201617: 49$

$3 / 3 / 201618: 11$

$3 / 3 / 201618: 16$

$3 / 3 / 201618: 21$

$3 / 3 / 201617: 54$

$3 / 3 / 201617: 59$

$3 / 3 / 201618: 04$

$3 / 3 / 201623: 58$

$3 / 4 / 20160: 03$

$3 / 4 / 20160: 08$

3/4/2016 0:13

3/4/2016 0:19

$3 / 4 / 2016$ 0:28 
$3 / 4 / 2016$ 0:33

$3 / 4 / 20160: 39$

$3 / 4 / 20160: 44$

$3 / 4 / 20160: 49$

$3 / 4 / 20164: 49$

$3 / 4 / 20164: 54$

$3 / 4 / 20165: 00$

$3 / 4 / 20165: 05$

$3 / 4 / 20165: 10$

$3 / 4 / 20165: 15$

$3 / 4 / 20165: 21$

$3 / 4 / 20165: 26$

$3 / 4 / 20165: 31$

$3 / 4 / 20165: 37$

$3 / 4 / 20165: 42$

$3 / 4 / 20165: 47$

$3 / 4 / 20165: 52$

$3 / 4 / 20165: 58$

$3 / 4 / 20166: 03$

$3 / 4 / 2016$ 6:08

10/10/2016 9:08

10/10/2016 9:13

10/10/2016 9:18

10/10/2016 9:23

10/10/2016 9:28

10/10/2016 9:33

10/10/2016 9:41

10/10/2016 9:46

10/10/2016 18:13

$10 / 10 / 201618: 18$

$10 / 10 / 201618: 23$

$10 / 10 / 201618: 29$

10/10/2016 18:34

10/10/2016 18:39

$10 / 10 / 201618: 44$

10/10/2016 18:50

10/10/2016 18:55

10/10/2016 19:00 


\section{Supplementary Information References}

Sparks, R.S.J., 1990. - written communication to University of Edinburgh

Wilson, S.A., 1997, The collection, preparation, and testing of USGS reference material 
BCR-2, Columbia River, Basalt: U.S. Geological Survey Open-File Report 
Supporting information

S2: OxCal age-depth model coding:

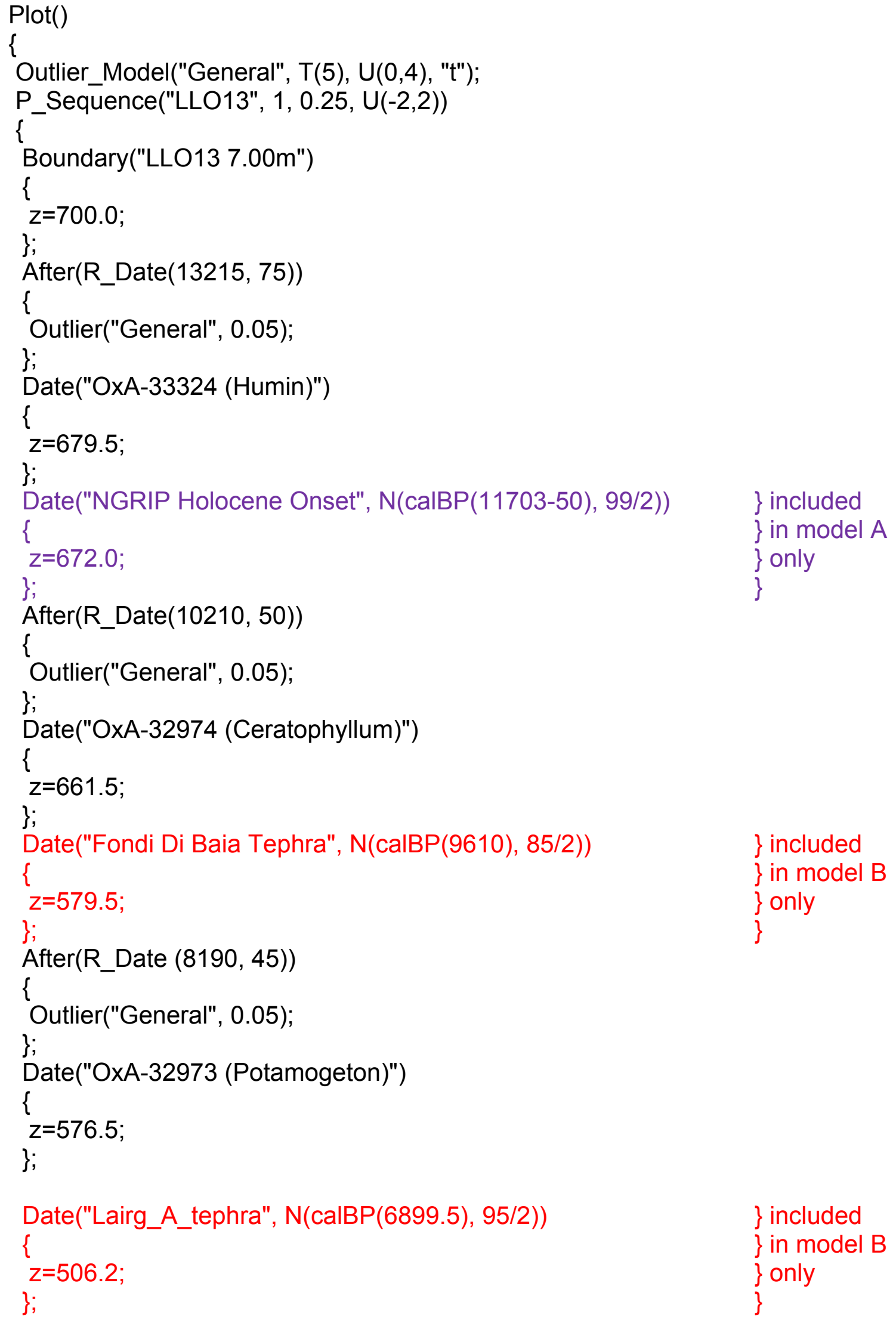




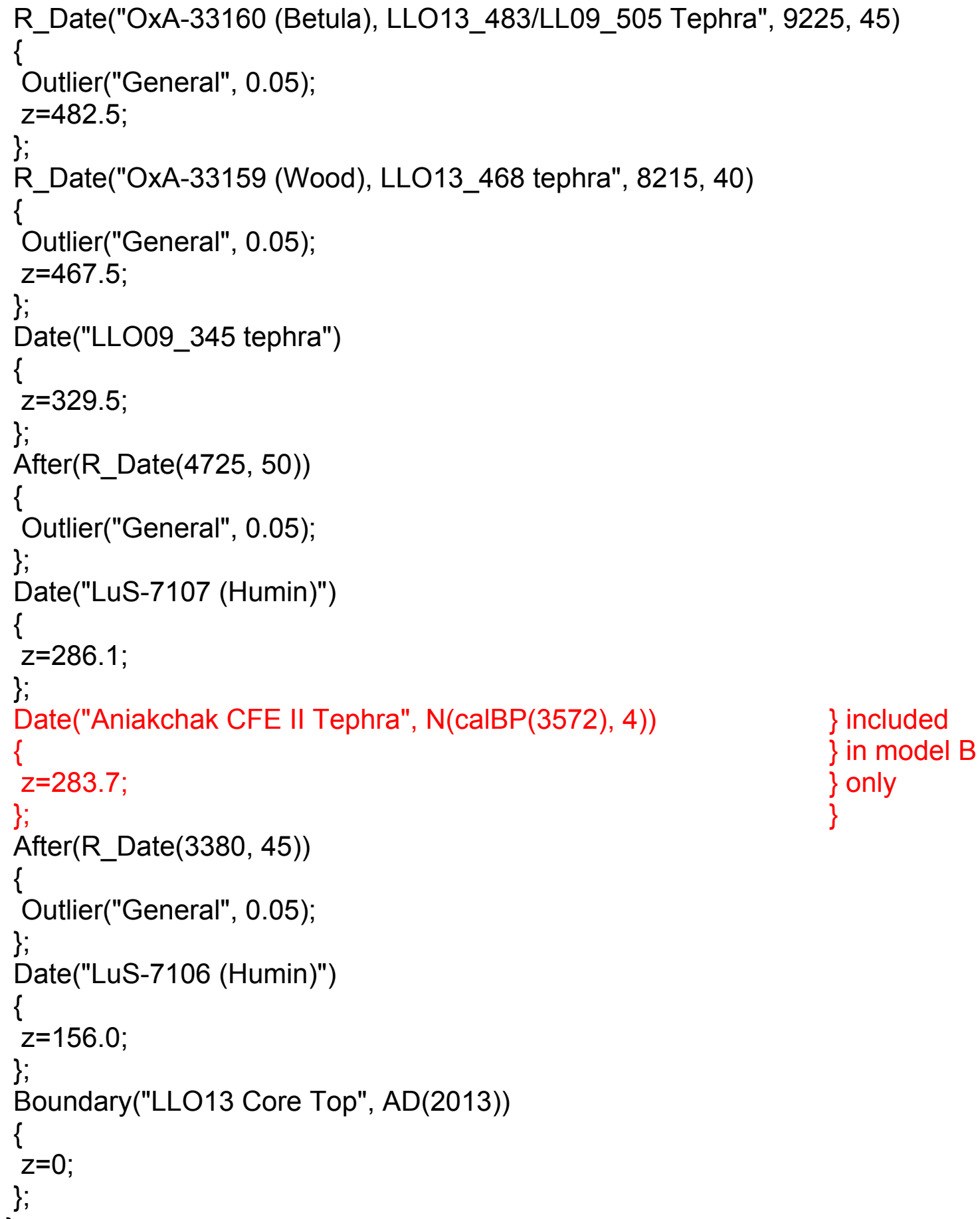

